\title{
A simple reactive-transport model of calcite precipitation in soils and other porous media
}

\author{
G.J.D. Kirk ${ }^{\mathrm{a}, *}$, A. Versteegen ${ }^{\mathrm{a}}$, K. Ritz ${ }^{\mathrm{a}}$, A.E. Milodowski ${ }^{\mathrm{b}}$ \\ ${ }^{a}$ School of Energy, Environment and Agrifood, Cranfield University, Cranfield, Bedford, \\ MK43 OAL, UK \\ ${ }^{\mathrm{b}}$ British Geological Survey, Keyworth, Nottingham, NG12 5GG, UK \\ Corresponding author. \\ E-mail address: q.kirk@cranfield.ac.uk (Guy Kirk).
}

\begin{abstract}
Calcite formation in soils and other porous media generally occurs around a localised source of reactants, such as a plant root or soil macro-pore, and the rate depends on the transport of reactants to and from the precipitation zone, as well as the kinetics of the precipitation reaction itself. However most studies are conducted using well-mixed systems, in which such transport limitations are largely removed. We developed a mathematical model of calcite precipitation near a source of base in soil, allowing for transport limitations and precipitation kinetics. We tested the model against experimentally-determined rates of calcite precipitation and reactant concentration:distance profiles in columns of soil in contact with a layer of $\mathrm{HCO}_{3}{ }^{-}$-saturated exchange resin. The model parameter values were determined independently. The agreement between observed and predicted results was satisfactory given experimental limitations, indicating that the model correctly describes the important processes. A sensitivity analysis showed that all model parameters are important, indicating a simpler treatment would be inadequate. The sensitivity analysis showed that the amount of calcite precipitated and the spread of the precipitation zone were sensitive to parameters controlling rates of reactant transport (soil moisture content, salt content, $\mathrm{pH}$, $\mathrm{pH}$ buffer power and $\mathrm{CO}_{2}$ pressure), as well as to the precipitation rate constant. We illustrate practical applications of the model with two examples, viz. the effect of $\mathrm{pH}$ changes and $\mathrm{CaCO}_{3}$ precipitation in the soil around a plant root, and around a soil macro-pore containing a source of base such as urea.
\end{abstract}

\section{INTRODUCTION}

Many important soil processes, such as changes in $\mathrm{pH}$ induced by plant roots, or the fate and effects of fertilizers, depend on the reactions of acids and bases with the soil and the possibility of $\mathrm{CaCO}_{3}$ precipitation. Plants roots often modify the $\mathrm{pH}$ of the soil around them to the extent that the $\mathrm{pH}$ at the root surface differs from that a few mm away by 1-2 units (Nye, 1981; Hinsinger, 2003; Neumann and Römheld, 2012). For example, a root rapidly absorbing nitrate will take up an excess of anions over cations and release bicarbonate into the soil to maintain charge balance across the root-soil boundary. The resulting increase in soil $\mathrm{pH}$ may be sufficient to cause $\mathrm{CaCO}_{3}$ precipitation on and near root surfaces, with important consequences for the access of nutrients and contaminants to the root. Likewise there are often large $\mathrm{pH}$ gradients near fertilizers in soils. For example the $\mathrm{pH}$ in the region of urea fertilizer may be 1-2 units higher than in the nearby soil, resulting in losses of nitrogen by $\mathrm{NH}_{3}$ volatilization (Rachhpal-Singh and Nye, 1986; Kirk 
and Nye, 1991). If $\mathrm{CaCO}_{3}$ precipitates in the zone of $\mathrm{pH}$ increase, this will curb the $\mathrm{pH}$ rise and thereby reduce the losses of $\mathrm{NH}_{3}$. There is currently particular interest in exploiting microbiallyenhanced urea hydrolysis in soils and sub-strata to stimulate $\mathrm{CaCO}_{3}$ precipitation for various applications such as physical stabilisation of soils (Stocks-Fischer et al., 1999; Chu et al., 2012), capture of heavy metals and radionuclides (Mitchell and Ferris., 2005; Fujita et al., 2010; Tobler et al., 2011), sealing of leaks in $\mathrm{CO}_{2}$ storage reservoirs (Ferris et al., 1996; Cunningham et al., 2009), and carbon sequestration (Dupraz et al., 2009; Mitchell et al., 2010; Renforth et al., 2009; Whitmore et al., 2014).

In all these examples the sources of the reactants forming $\mathrm{CaCO}_{3}$ are localised, and the rate of precipitation and spread of the precipitation zone depend on the rates of transport of the reactants into or out of the zone, as well as the precipitation kinetics at the nucleation sites per se. To model this system, so as to predict rates of precipitation and the dispersion of the precipitate through the soil or other media, it is therefore necessary to allow for both transport and precipitation kinetics. However, most work to date has been done with well-mixed systems without taking account of transport limitations. We know of no simple models that allow for both transport and precipitation kinetics.

The formation of $\mathrm{CaCO}_{3}$ from a saturated solution at near neutral $\mathrm{pH}$ can be represented:

$$
\mathrm{Ca}^{2+}+\mathrm{HCO}_{3}^{-}=\mathrm{CaCO}_{3}(\mathrm{~s})+\mathrm{H}^{+}
$$

The protons formed in the reaction will react with the soil solid or other substrate and with mobile bases in solution. The rate of the reaction in a zone in which the concentration of any of the reactants in Eq. 1 is changing will therefore depend on:

(1) the kinetics of the precipitation reaction, as influenced by the reactant activities, the presence of suitable nucleation sites, the concentrations of inhibitors, and other variables; and

(2) the rate of delivery of the reactants to the precipitation zone by diffusion or mass flow through the soil or substrate pore network with simultaneous release from solid phases.

Predicting rates of precipitation therefore requires an understanding of both the precipitation kinetics and the transport limitations.

The kinetics of $\mathrm{CaCO}_{3}$ precipitation in simple solution systems is quite well understood (reviewed by Morse et al., 2007) and models are available (Nielsen et al., 2013; Wolthers et al., 2014). But there is little equivalent information for soil systems and other porous media. Soil solutions are often supersaturated with respect to pure $\mathrm{CaCO}_{3}$ and precipitation is sensitive both to catalysis by existing $\mathrm{CaCO}_{3}$ and other solid surfaces, and to inhibition by organic and inorganic ligands in the soil solution (Inskeep and Bloom, 1986a,b; Amrhein et al., 1993; Lebron and Suarez, 1996, 1998; Hoch et al., 2000; Lin et al., 2005; Nielsen et al., 2013). Rates of transport in soil are generally far slower than in simple solution systems because most solutes are sorbed on soil surfaces and they are largely immobile in the sorbed state (Tinker and Nye, 2000; Sposito 2008).

In the work reported here we aimed to understand these processes well enough to develop a predictive mathematical model of them, which could be tested against independent experiments. In the paper we explain the development of the model and we test it against measured reactant concentration-distance profiles using independently-estimated model parameter values. We then make a sensitivity analysis of the model, firstly for the planar geometry of the experimental system used to test the model, and then in the cylindrical geometry appropriate for $\mathrm{CaCO}_{3}$ precipitation near a plant root or a soil macro-pore containing base. The paper is mainly concerned with soil systems but the model developed is also relevant to other biogeochemical systems such as those listed above. 


\section{THE MODEL}

\subsection{Planar geometry}

Consider the experimental system represented in Fig. 1. A column of $\mathrm{Ca}^{2+}$-saturated moist soil is in contact with a layer of anion exchange resin saturated with $\mathrm{HCO}_{3}{ }^{-}$. Over time, concentration profiles of the reactants develop in the soil as a result of the following processes:

(1) At the soil-resin boundary, $\mathrm{HCO}_{3}{ }^{-}$is released in exchange for $\mathrm{Cl}^{-}$in the soil solution. As a result, $\mathrm{Cl}^{-}$diffuses through the soil solution towards the resin and $\mathrm{HCO}_{3}{ }^{-}$diffuses in the opposite direction.

(2) Simultaneously, $\mathrm{HCO}_{3}{ }^{-}$reacts with soil acid (i.e. proton donating groups in the soil), tending to raise the soil $\mathrm{pH}$, and forming $\mathrm{CO}_{2}$ which diffuses away rapidly in the soil air.

(3) $\mathrm{HCO}_{3}{ }^{-}$also reacts with exchangeable $\mathrm{Ca}^{2+}$ ions in the soil to form $\mathrm{CaCO}_{3}$ and $\mathrm{H}^{+}$(Eq. 1), causing further acid-base changes and diffusion of $\mathrm{Ca}^{2+}$ towards the precipitation zone. The rise in $\mathrm{pH}$ resulting from the above reactions is propagated away by acid-base transfer through the soil solution: mainly of the acid $\mathrm{H}_{3} \mathrm{O}^{+}$from the soil bulk towards the reaction zone and the base $\mathrm{HCO}_{3}{ }^{-}$away.

(4) The movements of $\mathrm{Cl}^{-}, \mathrm{HCO}_{3}{ }^{-}$and $\mathrm{H}_{3} \mathrm{O}^{+}$induce balancing movements of $\mathrm{Ca}^{2+}$ (and to a lesser extent of other cations, $\mathrm{M}^{+}$) to maintain electrical neutrality.

In brief, the model allows for the diffusion of $\mathrm{HCO}_{3}{ }^{-}$, soil acidity, $\mathrm{Cl}^{-}$and $\mathrm{Ca}^{2+}$ to and from the zone of $\mathrm{CaCO}_{3}$ precipitation, and for the kinetics of $\mathrm{CaCO}_{3}$ precipitation using an empirical rate law. Diffusion equations are solved for the concentration-distance profiles of $\mathrm{HCO}_{3}{ }^{-}$, soil acidity and $\mathrm{Cl}^{-}$, and then the profile of $\mathrm{Ca}^{2+}$ is found by balancing ionic charges for electrical neutrality. Thereby the problem of defining the correct equations for $\mathrm{Ca}^{2+}$ diffusion with simultaneous cation exchange is avoided. The equations and boundary conditions are as follows (the nomenclature is explained in Table 1).

\subsubsection{Soil acidity}

The increase in $\mathrm{pH}$ in the reaction zone close to the resin is propagated away by diffusion of mobile acid-base pairs in the soil solution: acids from the soil bulk, which has a lower $\mathrm{pH}$, towards the resin, and bases in the opposite direction. Free protons do not exist in solution, so it is by the movements of acid-base pairs that $\mathrm{pH}$ changes are transferred through the soil. In our experimental system, the two main acid-base pairs are $\mathrm{H}_{3} \mathrm{O}^{+}-\mathrm{H}_{2} \mathrm{O}$ and $\mathrm{H}_{2} \mathrm{CO}_{3}-\mathrm{HCO}_{3}{ }^{-}$; the pair $\mathrm{HCO}_{3}{ }^{-}-\mathrm{CO}_{3}{ }^{2-}$ is only important at very high $\mathrm{pH}$. If the soil bulk is more than slightly acid, there will be more $\mathrm{H}_{3} \mathrm{O}^{+}$in solution than $\mathrm{HCO}_{3}{ }^{-}$; whereas close to the resin $\mathrm{HCO}_{3}{ }^{-}$will greatly exceed $\mathrm{H}_{3} \mathrm{O}^{+}$. Hence, a small portion of soil may gain acidity by access of $\mathrm{H}_{3} \mathrm{O}^{+}$:

$$
\text { Soil-M }+\mathrm{H}_{3} \mathrm{O}^{+}=\text {Soil- } \mathrm{H}+\mathrm{M}^{+}+\mathrm{H}_{2} \mathrm{O}
$$

or it may lose acidity by the arrival of $\mathrm{HCO}_{3}{ }^{-}$and formation of $\mathrm{H}_{2} \mathrm{CO}_{3}$, followed by removal of $\mathrm{CO}_{2}$ through the soil air:

$$
\text { Soil- } \mathrm{H}+\mathrm{M}^{+}+\mathrm{HCO}_{3}^{-}=\text {Soil-M }+\mathrm{H}_{2} \mathrm{CO}_{3}
$$

Therefore, the continuity equation for changes in soil acidity is (after Nye, 1972) 


$$
\frac{\partial[\mathrm{HS}]}{\partial t}=\frac{\partial}{\partial x} \theta f\left(D_{\mathrm{LH}} \frac{\mathrm{d}\left[\mathrm{H}_{3} \mathrm{O}^{+}\right]}{\mathrm{d} x}-D_{\mathrm{LB}} \frac{\mathrm{d}\left[\mathrm{HCO}_{3}{ }^{-}\right]}{\mathrm{d} x}\right)+2 R
$$

where [HS] is the concentration of titratable acidity, as measured by the amount of strong base consumed per unit soil volume in increasing the soil solution to a standard $\mathrm{pH} ; R$ is rate of $\mathrm{CaCO}_{3}$ precipitation; $D_{\mathrm{LH}}$ and $D_{\mathrm{LB}}$ are the diffusion coefficients of $\mathrm{H}_{3} \mathrm{O}^{+}$and $\mathrm{HCO}_{3}{ }^{-}$in free solution; $\theta$ is the soil water content by volume; and $f$ is an empirical impedance factor, allowing for the geometry of the soil pore network and ion exclusion from narrow pores, and held to be the same for all simple ions in a given soil (Tinker and Nye, 2000).

Note it is assumed that the equilibria in Eqs (2) and (3) are rapid compared with diffusion. If they are not, additional rate of reaction terms can be added to the equation, but to do so at this stage would unduly complicate the model. Note also $R$ is multiplied by two because each mol of $\mathrm{CaCO}_{3}$ precipitated generates $2 \mathrm{~mol}$ of acidity through the consumption of $1 \mathrm{~mol}$ of $\mathrm{HCO}_{3}{ }^{-}$and production of $1 \mathrm{~mol}$ of $\mathrm{H}^{+}$.

To solve Eq. (4) we need to express the concentration terms in terms of a common variable. It is convenient to use $\mathrm{HCO}_{3}{ }^{-}$for this because it is the dominant species in the reaction zone. We express $\mathrm{d}[\mathrm{HS}]$ in terms of $\mathrm{d}\left[\mathrm{HCO}_{3}{ }^{-}\right]$as follows.

First we define the $\mathrm{pH}$ buffer power ${ }^{1}$ of the soil as

$$
b_{\mathrm{HS}}=-\frac{\mathrm{d}[\mathrm{HS}]}{\mathrm{dpH}}
$$

In many soils, $b_{\mathrm{HS}}$ is fairly constant over a wide $\mathrm{pH}$ range (Nye, 1972). Therefore, in Eq. (4),

$$
\mathrm{d}[\mathrm{HS}]=\frac{\mathrm{d}[\mathrm{HS}]}{\mathrm{dpH}} \mathrm{dpH}=-b_{\mathrm{HS}} \mathrm{dpH}
$$

Now, considering the dissociation of $\mathrm{H}_{2} \mathrm{CO}_{3}$ :

$$
\left[\mathrm{HCO}_{3}^{-}\right]=\frac{K_{1} K_{\mathrm{S}} P_{\mathrm{CO}_{2}}}{\left[\mathrm{H}_{3} \mathrm{O}^{+}\right]}
$$

where $K_{1}$ is the apparent first dissociation constant of $\mathrm{H}_{2} \mathrm{CO}_{3}, K_{\mathrm{S}}$ is the solubility of $\mathrm{CO}_{2}$ in water and $P_{\mathrm{CO}_{2}}$ is the pressure of $\mathrm{CO}_{2}$ in the soil air. $\mathrm{CO}_{2}$ diffuses sufficiently rapidly in the soil air that $P_{\mathrm{CO}_{2}}$ can be taken as constant (Appendix). Therefore, $K_{1} K_{\mathrm{S}} P_{\mathrm{CO}_{2}}$ is constant, and taking logs on

\footnotetext{
${ }^{1}$ It is conventional in soil science to refer to the soil pH buffer power, not capacity, because we are concerned with changes in concentration of soil acidity per unit pH change, i.e., the relation between two 'intensity' factors; whereas the buffer capacity of a solution is the change in amount of acid per unit $\mathrm{pH}$ change, i.e., the relation between a 'capacity' factor and an intensity factor.
} 
both sides of Eq. (7) and differentiating gives

$$
\mathrm{dpH}=-\mathrm{dp}\left[\mathrm{HCO}_{3}{ }^{-}\right]=\frac{\mathrm{d}\left[\mathrm{HCO}_{3}{ }^{-}\right]}{2.303\left[\mathrm{HCO}_{3}{ }^{-}\right]}
$$

Combining Eq. (8) with Eq. (6) gives

$$
\mathrm{d}[\mathrm{HS}]=-\frac{b_{\mathrm{HS}}}{2.303\left[\mathrm{HCO}_{3}^{-}\right]} \mathrm{d}\left[\mathrm{HCO}_{3}^{-}\right]
$$

Combining Eq. (9) with Eq. (4) and rearranging gives

$$
\frac{\partial\left[\mathrm{HCO}_{3}{ }^{-}\right]}{\partial t}=\frac{2.303\left[\mathrm{HCO}_{3}{ }^{-}\right]}{b_{\mathrm{HS}}}\left[\theta f \frac{\partial}{\partial x}\left(D_{\mathrm{LB}} \frac{\mathrm{d}\left[\mathrm{HCO}_{3}{ }^{-}\right]}{\mathrm{d} x}-D_{\mathrm{LH}} \frac{\mathrm{d}\left[\mathrm{H}_{3} \mathrm{O}^{+}\right]}{\mathrm{d} x}\right)-2 R\right]
$$

This is the working continuity equation for soil acidity with $\mathrm{HCO}_{3}{ }^{-}$as the working variable. Alternatively, $\mathrm{pH}$ can be used as the working variable. We have.

$$
\mathrm{d}\left[\mathrm{H}_{3} \mathrm{O}^{+}\right]=\frac{\mathrm{d}\left[\mathrm{H}_{3} \mathrm{O}^{+}\right]}{\mathrm{dpH}} \mathrm{dpH}=-2.303\left[\mathrm{H}_{3} \mathrm{O}^{+}\right] \mathrm{dpH}
$$

and

$$
\mathrm{d}\left[\mathrm{HCO}_{3}{ }^{-}\right]=\frac{\mathrm{d}\left[\mathrm{HCO}_{3}{ }^{-}\right]}{\mathrm{dpH}} \mathrm{dpH}=2.303\left[\mathrm{HCO}_{3}{ }^{-}\right] \mathrm{dpH}
$$

Combining Eqs (6), (11) and (12) with Eq. (4) gives

$$
\frac{\partial \mathrm{pH}}{\partial t}=\frac{\partial}{\partial x}\left[\left\{\frac{2.303 \theta f}{b_{\mathrm{HS}}}\left(D_{\mathrm{LH}}\left[\mathrm{H}_{3} \mathrm{O}^{+}\right]+D_{\mathrm{LB}}\left[\mathrm{HCO}_{3}{ }^{-}\right]\right) \frac{\mathrm{dpH}}{\mathrm{d} x}\right]-\frac{2 R}{b_{\mathrm{HS}}}\right.
$$

The term in the curly brackets in Eq. (13) is the soil acidity diffusion coefficient, $D_{\mathrm{HS}}$ :

$$
D_{\mathrm{HS}}=\frac{2.303 \theta f}{b_{\mathrm{HS}}}\left(D_{\mathrm{LH}}\left[\mathrm{H}_{3} \mathrm{O}^{+}\right]+D_{\mathrm{LB}}\left[\mathrm{HCO}_{3}^{-}\right]\right)
$$

We use Eq. (14) later to discuss the pH-dependence of soil acidity diffusion.

\subsubsection{Chloride}

Chloride ions are largely not adsorbed on soil surfaces (Sposito, 2008) and we treat them as 
being wholly in the soil solution. The continuity equation for the diffusion of $\mathrm{Cl}^{-}$through the soil is therefore

$$
\begin{aligned}
& \frac{\partial \theta\left[\mathrm{Cl}^{-}\right]}{\partial t}=\frac{\partial}{\partial x}\left(\theta f D_{\mathrm{LCl}} \frac{\mathrm{d}\left[\mathrm{Cl}^{-}\right]}{\mathrm{d} x}\right) \\
& \text { i.e. } \frac{\partial\left[\mathrm{Cl}^{-}\right]}{\partial t}=\frac{\partial}{\partial x}\left(f D_{\mathrm{LCl}} \frac{\mathrm{d}\left[\mathrm{Cl}^{-}\right]}{\mathrm{d} x}\right)
\end{aligned}
$$

where $\left[\mathrm{Cl}^{-}\right]$is the concentration of $\mathrm{Cl}^{-}$in the soil solution.

\subsubsection{Calcium}

From electrical neutrality and considering all potentially important ions in the soil solution:

$$
2\left[\mathrm{Ca}^{2+}\right]+\left[\mathrm{CaCl}^{+}\right]+\left[\mathrm{CaHCO}_{3}{ }^{+}\right]+\left[\mathrm{M}^{+}\right]+\left[\mathrm{H}_{3} \mathrm{O}^{+}\right]=\left[\mathrm{Cl}^{-}\right]+\left[\mathrm{HCO}_{3}{ }^{-}\right]+2\left[\mathrm{CO}_{3}{ }^{2-}\right]+\left[\mathrm{OH}^{-}\right]
$$

where $\mathrm{M}^{+}$represents other cations (e.g. $\mathrm{Na}^{+}$and $\mathrm{K}^{+}$). Calculations with the MINTEQ speciation model (Gustafsson, 2012) show that the concentrations of charged organic species in the soil solution will be unimportant compared with the inorganic species. With DOC concentration $=15$ $\mathrm{mM}$ (Section 4.1.1), organic anions were less than $1 \%$ of the total anionic charge over the range of conditions in our experimental system, and less than $2 \%$ of the Ca in solution was complexed with organic ligands. We therefore do not explicitly allow for organic complexes in Eq. (16). In solving Eq. (16) we assume the concentration of $\mathrm{M}^{+}$in solution is constant; the justification for this is discussed in Section 4.1.2.

\subsubsection{Kinetics of $\mathrm{CaCO}_{3}$ precipitation}

The rate of precipitation at any point in the soil will depend on the degree of saturation of the soil solution, the solution stoichiometry, the mechanisms of precipitation, nucleation surfaces, the presence of inhibitors (e.g. dissolved organic C) and other factors (Morse et al., 2007). In soil, precipitates form as discontinuous coatings on the surfaces of soil pores, so the precipitation surface area and geometry are indeterminate. However, if the soil solution is strongly oversaturated, as it is in our experimental system in the region of the resin (Section 3.2), the degree of over-saturation is the main determinant of nucleation and crystal growth and the following empirical rate law often works well (Stumm and Morgan, 1996):

$$
R=\alpha(\Omega-1)
$$

where $\Omega$ is the saturation ratio (= $I A P / K_{\mathrm{SP}}$ where $I A P$ is the ion activity product and $K_{\mathrm{SP}}$ the solubility product) and $\alpha$ an empirical rate coefficient.

We fit Eq. (17) to the experimental data and discuss in Section 4.2.3 how the fitted value of $\alpha$ compares with published precipitation rate constants. We assume that the $\mathrm{CaCO}_{3}$ formed is calcite, as confirmed by the experimental results (Section 4.1.2), and we use $\mathrm{p} K_{\mathrm{SP}}=8.48$ (Plummer and Busenberg, 1983). We calculate ion activity coefficients using the Davies 
equation.

\subsubsection{Initial and boundary conditions}

Soil acidity. The flux of $\mathrm{HCO}_{3}{ }^{-}$across the resin surface is equal to the flux of $\mathrm{Cl}^{-}$in the opposite direction. It is also equal to the flux of acidity through the soil. There is no transfer of acidity across the opposite end of the soil column. Hence the initial and boundary conditions for Eq. (10) are

$$
\begin{array}{lll}
\mathrm{pH}=\mathrm{pH}_{\text {initial }} & 0 \leq x \leq L & t=0 \\
\theta f\left(D_{\mathrm{LH}} \frac{\mathrm{d}\left[\mathrm{H}_{3} \mathrm{O}^{+}\right]}{\mathrm{d} x}-D_{\mathrm{LB}} \frac{\mathrm{d}\left[\mathrm{HCO}_{3}^{-}\right]}{\mathrm{d} x}\right)=\theta f D_{\mathrm{LCl}} \frac{\mathrm{d}\left[\mathrm{Cl}^{-}\right]}{\mathrm{d} x} & x=0 & t>0 \\
\theta f\left(D_{\mathrm{LH}} \frac{\mathrm{d}\left[\mathrm{H}_{3} \mathrm{O}^{+}\right]}{\mathrm{d} x}-D_{\mathrm{LB}} \frac{\mathrm{d}\left[\mathrm{HCO}_{3}^{-}\right]}{\mathrm{d} x}\right)=0 & x=L & t>0
\end{array}
$$

Chloride. From the experimental results, the balance between the flux of $\mathrm{HCO}_{3}{ }^{-}$from the resin into the soil and the flux of $\mathrm{Cl}^{-}$in the opposite direction is such that a roughly constant concentration of $\mathrm{Cl}^{-}$at is maintained at the resin surface $(x=0)$, i.e. $\left[\mathrm{Cl}^{-}\right]=\left[\mathrm{Cl}^{-}\right]_{0}$. At the opposite end of the soil column $(x=L)$, there is no transfer of $\mathrm{Cl}^{-}$out of the soil, i.e. the flux of $\mathrm{Cl}^{-}$is zero. Hence the initial and boundary conditions for Eq. (15) are

$$
\begin{array}{lll}
{\left[\mathrm{Cl}^{-}\right]=\left[\mathrm{Cl}^{-}\right]_{\text {initial }}} & 0 \leq x \leq L & t=0 \\
{\left[\mathrm{Cl}^{-}\right]=\left[\mathrm{Cl}^{-}\right]_{0}} & x=0 & t>0 \\
\theta f D_{\mathrm{LCl}} \frac{\mathrm{d}[\mathrm{Cl}]}{\mathrm{d} x}=0 & x=L & t>0
\end{array}
$$

In the model, Eqs (10), (15) and (16) are solved simultaneously, subject to the initial and boundary conditions, using standard numerical methods. The program for the model is written in FORTRAN. Copies are available from the Corresponding Author.

\subsection{Cylindrical geometry}

For $\mathrm{CaCO}_{3}$ precipitation around a plant root or a cylindrical soil macro-pore, we modify the approach for the planar experimental system as follows.

We consider a constant pre-set flux of $\mathrm{HCO}_{3}{ }^{-}$across the root or macro-pore surface, so that we can compare the effects of the range of fluxes expected for natural and artificial systems. The release of $\mathrm{HCO}_{3}{ }^{-}$induces a rise in $\mathrm{pH}$ and other changes in the soil as described in Section 2.1. For simplicity, we consider that the concentrations of $\mathrm{Ca}$ and other cations in the soil solution are sufficiently buffered by the soil exchange complex and by transport in from the bulk soil that they are effectively constant. It is then only necessary to solve the equations for soil acidity 
diffusion and reaction, expressed in cylindrical geometry, and the equation for electrical neutrality (Eq. 16) for the speciation of Ca. The equations and boundary conditions in cylindrical geometry are as follows.

Consider a hollow cylinder of internal radius $r=a$ and outer radius $r=b$. The boundary $r=a$ represents the plant root or macro-pore surface, and the boundary $r=b$ represents the mid-point between adjacent roots or pores. (For reference, with a regular parallel array of roots or pores, of length per unit soil volume $L_{\mathrm{V}}$, the mean value of $b=1 / \sqrt{\pi L_{\mathrm{V}}}$.) The form of Eq. (10) in cylindrical geometry is

$$
\frac{\partial\left[\mathrm{HCO}_{3}{ }^{-}\right]}{\partial t}=\frac{2.303\left[\mathrm{HCO}_{3}{ }^{-}\right]}{b_{\mathrm{HS}}}\left[\frac{1}{r} \frac{\partial}{\partial r} r \theta f\left(D_{\mathrm{LB}} \frac{\mathrm{d}\left[\mathrm{HCO}_{3}{ }^{-}\right]}{\mathrm{d} r}-D_{\mathrm{LH}} \frac{\mathrm{d}\left[\mathrm{H}_{3} \mathrm{O}^{+}\right]}{\mathrm{d} r}\right)-2 R\right]
$$

If the flux of $\mathrm{HCO}_{3}{ }^{-}\left(F_{\mathrm{B}}\right)$ across $r=a$ is constant and there is no transfer across $r=b$, then the initial and boundary conditions are

$$
\begin{array}{lll}
\mathrm{pH}=\mathrm{pH}_{\text {initial }} & a \leq r \leq b & t=0 \\
-\theta f\left(D_{\mathrm{LB}} \frac{\mathrm{d}\left[\mathrm{HCO}_{3}{ }^{-}\right]}{\mathrm{d} r}-D_{\mathrm{LH}} \frac{\mathrm{d}\left[\mathrm{H}_{3} \mathrm{O}^{+}\right]}{\mathrm{d} r}\right)=F_{\mathrm{B}} & r=a & t>0 \\
-\theta f\left(D_{\mathrm{LB}} \frac{\mathrm{d}\left[\mathrm{HCO}_{3}^{-}\right]}{\mathrm{d} r}-D_{\mathrm{LH}} \frac{\mathrm{d}\left[\mathrm{H}_{3} \mathrm{O}^{+}\right]}{\mathrm{d} r}\right)=0 & r=b & t>0
\end{array}
$$

These equations are solved numerically as for the planar model. Copies of the program, written in FORTRAN, are available from the Corresponding Author.

\section{EXPERIMENTAL METHODS}

\subsection{Experimental soil}

The soil was obtained from 0-15 cm depth of an argillic brown earth (Ashley series) under pasture grass near Ridgmont, Bedfordshire, England (National Grid Reference SP 99292 34545), as described by Corstanje et al. (2008). Preliminary experiments showed that this soil has appropriate physical and chemical characteristics for our experimental system. Its properties after air-drying and sieving to $<2 \mathrm{~mm}$ were: $\mathrm{pH}$ (in $10 \mathrm{mM} \mathrm{CaCl}_{2}$ ) 5.7, cation exchange capacity 23 $\mathrm{cmol}_{\mathrm{C}} \mathrm{kg}^{-1}$, organic C content $45 \mathrm{~g} \mathrm{~kg}^{-1}$, dissolved organic $\mathrm{C}$ (in $10 \mathrm{mM} \mathrm{CaCl}_{2}$ and passed through a $0.22-\mu \mathrm{m}$ filter) $15 \mathrm{mM}$ and sand:silt:clay 0.45:0.21:0.34. The clay fraction is predominantly smectite. The soil was washed three times with $10 \mathrm{mM} \mathrm{CaCl}_{2}$ at a solution:soil ratio of 1.5:1, discarding the supernatant after each washing and finally air drying and re-sieving to $<0.5 \mathrm{~mm}$. 
An estimate of the soil pH buffer power (Eq. 4) was obtained as follows. Triplicate $22 \mathrm{~g}$ portions of the air-dried soil were shaken for $1 \mathrm{~h}$ with $55 \mathrm{~cm}^{3}$ of $10 \mathrm{mM} \mathrm{CaCl}_{2}$ containing graded amounts of $\mathrm{NaOH}$ (sufficient to give $0,12.5$ or $31 \mathrm{mmol} \mathrm{OH}^{-} \mathrm{kg}^{-1}$ (soil), resulting in $\mathrm{pH}$ increases of $0-2$ units). The suspension pHs were then measured using a combination electrode, and 10 $\mathrm{cm}^{3}$ aliquots were removed for analysis of the $\mathrm{CaCO}_{3}$ precipitated by filtering (Whatman GFP filter papers), acidifying the soil residue $\left(5 \mathrm{~cm}^{3} 1 \mathrm{M} \mathrm{HCl}\right)$ and measuring the $\mathrm{CO}_{2}$ evolved by gas chromatography. The $\mathrm{pH}$ buffer power $b_{\mathrm{Hs}}$ was calculated from the addition of $\mathrm{OH}^{-}$, less $\mathrm{OH}^{-}$ consumed in $\mathrm{CaCO}_{3}$ precipitation, divided by the $\mathrm{pH}$ change.

\subsection{Testing of the model}

Experimental units were constructed according to the scheme in Fig. 1. Air-dry soil was packed into 0.4-dm internal diameter, 0.3-dm long Perspex cells to a bulk density of approx. $1 \mathrm{~kg}$ $\mathrm{dm}^{-3}$. The bottoms of the cells were covered with $24 \mu \mathrm{m}$ pore-diameter nylon mesh and they were then placed on watch glasses containing $10 \mathrm{mM} \mathrm{CaCl}_{2}$ solution and allowed to equilibrate overnight to bring the water content to approx. $0.5 \mathrm{dm}^{3}$ (solution) $\mathrm{dm}^{-3}$ (soil) by capillary rise. The addition of solution made the soils swell by 1 or $2 \mathrm{~mm}$ beyond the rim of the cells; the excess soil was removed to produce a flat surface. The packed cells were placed in an incubation chamber with a water-saturated atmosphere and connected to the outside atmosphere via a HEPA filter to allow gas exchange.

Meanwhile, 1-cm thick layers of $\mathrm{HCO}_{3}{ }^{-}$-form anion exchange resin (Amberlite IRA-400, ion exchange capacity $1.40 \mathrm{~mol}_{\mathrm{C}} \mathrm{dm}^{-3}$ (wetted bed)) were made in further 0.4-dm internal diameter Perspex cells, and their water content adjusted on sand tables to match the water potential of the soil. The resin layers were then placed in contact with the soil columns, separated by $24 \mu \mathrm{m}$ porediameter nylon mesh. To ensure good soil-mesh-resin contact, rubber bungs were placed in the resin cells and pushed down. Silicone grease was spread over the joins between the two cells to reduce water loss. The systems were incubated at $20^{\circ} \mathrm{C}$ in a water-saturated environment as above.

After 1 and 5 days of resin-soil contact, the cells were separated and the soil sectioned at $0.5-1$ $\mathrm{mm}$ intervals parallel to the resin-soil boundary using a hand microtome (Griffin and George, type DIEH 600-B) and a stainless steel blade. Each soil section was weighed in a Millipore Ultrafree Centrifugal Filter Device with a $0.22 \mu \mathrm{m}$ membrane, and then centrifuged at $2.8 \mathrm{~g}$ for 10 min to extract the soil solution. The $\mathrm{pH}$ of the soil solution extracted was measured immediately with a combination electrode and its volume determined by weight. The solution was then diluted with deionised water and analysed for Ca by atomic absorption spectrometry (Perkin Elmer Analyst 800) and for $\mathrm{Cl}$ by ion exchange chromatography (Dionex DX500). The $\mathrm{CaCO}_{3}$ contents of the sections were measured by acidifying and measuring $\mathrm{CO}_{2}$ evolved as in Section 3.1. Mean standard errors of soil analyses by these methods were 0.03 for $\mathrm{pH}, 0.5 \mathrm{mM}$ for $\mathrm{Ca}$ and $\mathrm{Cl}$ concentrations in solution and $0.15 \mathrm{mmol} \mathrm{kg}^{-1}$ for $\mathrm{CaCO}_{3}$ precipitated.

The water contents of the cells were determined by drying the un-sectioned residual soil at $105^{\circ} \mathrm{C}$ overnight and measuring water loss. The bulk densities were determined from the mass of dry soil per unit cell volume. The distance of each soil section from the resin boundary was calculated from the section dry weights and the bulk density. In preliminary experiments, cells packed and incubated in the same way were sectioned parallel to the surface and the section water contents and dry weights determined. This showed that the bulk density and water content were constant with depth through the soil to within $\pm 2 \%$. 
The crystalline form of $\mathrm{CaCO}_{3}$ precipitated was assessed in replicate soil columns sectioned and immediately analysed by environmental scanning electron microscopy (ESEM; FEI QUANTA 600 using a water-vapour atmosphere) with qualitative energy-dispersive X-ray microanalysis (EDXA) to aid identification of phases observed under ESEM. X-ray diffraction (XRD) was subsequently carried out to confirm the calcium carbonate mineral polytypes.

\section{RESULTS AND DISCUSSION}

\subsection{Testing of the model}

\subsubsection{Model parameter values}

From the set-up of the soil columns, $L$ (length of column) $=0.3 \mathrm{dm}, \rho$ (bulk density) $=0.95 \mathrm{~kg}$ $\mathrm{dm}^{-3}$ and $\theta$ (volumetric water content) $=0.53 \mathrm{dm}^{3}$ (solution) $\mathrm{dm}^{-3}$ (soil). From the measured concentrations in the soil uninfluenced by resin, the initial composition of the soil solution was $[\mathrm{Ca}]=25 \mathrm{mM},[\mathrm{Cl}]=80 \mathrm{mM},\left[\mathrm{M}^{+}\right]=30 \mathrm{mM}$ and $\mathrm{pH}=6.1$. The determination blank for $\mathrm{CaCO}_{3}(\mathrm{~s})$ in the soil was $2 \mathrm{mmol} \mathrm{kg}^{-1}$. From the results of the soil titration with $\mathrm{NaOH}$ in shaken suspensions (Section 3.1), $b_{\mathrm{HS}}=15 \mathrm{mmol}\left(\mathrm{OH}^{-}\right) \mathrm{kg}^{-1}$ (soil) $\mathrm{pH}^{-1}$. The values of the diffusion coefficients in free solution $\left(D_{\mathrm{L}}\right)$ used were 9.55, 1.23 and $2.00 \times 10^{-7} \mathrm{dm}^{2} \mathrm{~s}^{-1}$ for $\mathrm{H}_{3} \mathrm{O}^{+}, \mathrm{HCO}_{3}^{-}$ and $\mathrm{Cl}^{-}$, respectively (Kirk, 2004).

The chloride concentration-distance profiles are independent of the other profiles and $\mathrm{CaCO}_{3}$ precipitation; they solely depend on the solution of Eq. (15) subject to the boundary conditions. Therefore the diffusion impedance factor $(f)$ and the concentration of $\mathrm{Cl}^{-}$at the resin-soil boundary $\left(\left[\mathrm{Cl}^{-}\right]_{0}\right)$ can be found from fits of Eq. (15) to the experimental data. From the $\mathrm{Cl}^{-}$ concentration-distance profiles in Fig. $2,[\mathrm{Cl}]_{0}=30 \mathrm{mM}$, and, by fitting Eq. (15) to the data, $f=$ 0.25 .

We then estimated the $\mathrm{CO}_{2}$ pressure in the soil columns and the value of $\alpha$ by running the model with a range of values of $\mathrm{CO}_{2}$ pressure and $\alpha$, with the other parameter values as above, and choosing the values giving the best fits (by eye) to the $\mathrm{pH}$ and $\mathrm{CaCO}_{3}$ profiles in Fig. 2. This gave $P_{\mathrm{CO}_{2}}=0.5 \mathrm{kPa}(0.005 \mathrm{~atm})$, which is typical of a moist grassland soil, and $\alpha=5 \times 10^{-10} \mathrm{~mol}$

$\mathrm{dm}^{-3}$ (soil) $\mathrm{s}^{-1}$. Based on the model fits to the data, and the sensitivity to $\alpha$ of the predicted amount of $\mathrm{CaCO}_{3}$ precipitated, its spread through the soil, and the $\mathrm{pH}$ change at the resin-soil boundary (Section 4.3.3), the error on the estimate of $\alpha$ is of the order $\pm 2 \times 10^{-10} \mathrm{~mol} \mathrm{dm}^{-3}$ (soil) s ${ }^{-1}$.

\subsubsection{Observed and predicted concentration-distance profiles}

Figure 2 shows the experimental and calculated profiles of $\mathrm{Ca}$ and $\mathrm{Cl}$ concentrations in solution, the soil $\mathrm{pH}$ and the $\mathrm{CaCO}_{3}$ precipitated after 1 and 5 days of resin-soil contact.

Chloride. In Fig. 2A and B there is a zone of salt depletion in the soil close to the resin where $\mathrm{Cl}^{-}$in the soil solution has been replaced by $\mathrm{HCO}_{3}{ }^{-}$from the resin, which has then been removed as $\mathrm{CO}_{2}$ in the soil air following reaction with $\mathrm{H}^{+}$. The zone of $\mathrm{Cl}^{-}$depletion, and with it the zone of overall salt depletion, spreads far into the soil. This is because $\mathrm{Cl}^{-}$is not adsorbed on soil surfaces (Section 2.1.1), and so its diffusion coefficient in the soil is large.

$\mathrm{pH}$. By contrast the zone of $\mathrm{pH}$ increase is narrow: after $1 \mathrm{~d}$, the spread of the $\mathrm{pH}$ profile (as gauged by the distance at which the $\mathrm{pH}$ increase is $<5 \%$ of the maximum increase) is $6.6 \mathrm{~mm}$ whereas the spread of the $\mathrm{Cl}$ profile (same basis) is $16.7 \mathrm{~mm}$ (Fig. $2 \mathrm{C}$ and $\mathrm{D}$ ). $\mathrm{Had}^{\mathrm{HCO}_{3}{ }^{-} \text {not }}$ 
reacted with the soil, it would have diffused over a similar distance to the zone of $\mathrm{Cl}^{-}$depletion because the diffusion coefficients of these ions are relatively similar. The shape of the $\mathrm{pH}$ profile is also very different to that of $\mathrm{Cl}^{-}$: it is shallow close to the resin but progressively steeper with distance into the soil. The explanation is to do with the variation of the soil acidity diffusion coefficient, $D_{\mathrm{HS}}$, with $\mathrm{pH}$ shown in Eq. 14 . Where $\left[\mathrm{HCO}_{3}{ }^{-}\right]$is large, near the resin, $D_{\mathrm{Hs}}$ is large and the $\mathrm{pH}$ profile is shallow, and where $\left[\mathrm{HCO}_{3}{ }^{-}\right]$is small (and $\left[\mathrm{H}_{3} \mathrm{O}^{+}\right]$relatively small), $D_{\mathrm{HS}}$ is small and the profile is steep. Note the modelled $\mathrm{pH}$ near the resin decreases slightly over time, from 8.5 at 1 day to 8.3 at 5 days. This is because the flux of $\mathrm{Cl}^{-}$from the resin decreases over time as $\mathrm{Cl}^{-}$is depleted, and therefore the release of $\mathrm{HCO}_{3}{ }^{-}$from the resin must decrease.

Note also there is some tailing in the measured, but not the modelled, $\mathrm{pH}$ profile far from the resin at $5 \mathrm{~d}$. This is probably because of time-dependency in the $\mathrm{pH}$ buffering reactions, which means that some of the $\mathrm{HCO}_{3}{ }^{-}$reacts slowly with the soil, and so moves ahead of the main profile. The experimental soil is quite humose, and, over the $\mathrm{pH}$ range in the experiments, the buffering reactions probably involve soil organic groups as well as $\mathrm{pH}$-dependent charge on soil clays. Slow buffering reactions may involve slow access to hidden organic and inorganic sites, for example within soil particles (Ptashnyk et al., 2010, discuss such effects). At any rate, this is a minor effect and does not merit the additional complexity that would be required to include it in the model. Given the large number of independently-measured variables involved in the model calculations, and the sensitivity of the model to them (Section 4.2), the agreement between the observed and predicted $\mathrm{pH}$ profiles is good.

Calcium. The agreement for the profiles of $\mathrm{Ca}$ in solution (i.e. $\left[\mathrm{Ca}^{2+}\right]+\left[\mathrm{CaCl}^{+}\right]+\left[\mathrm{CaHCO}_{3}^{+}\right]$ $\left.+\left[\mathrm{CaCO}_{3}{ }^{0}\right]\right)$ is less good, especially close to the resin boundary in the early stages. We suggest this is because the simplified treatment of Ca diffusion in the model - whereby the Ca cations are treated as balancing ions which change in response to the changes in $\mathrm{Cl}^{-}$and $\mathrm{HCO}_{3}{ }^{-}$, with the other cations present $\left(\mathrm{M}^{+}\right)$constant - fails in the early stages of the experiment. This is explained as follows.

Reaction of $\mathrm{HCO}_{3}{ }^{-}$with $\mathrm{H}^{+}$in the soil will cause $\mathrm{H}^{+}$to be released from soil surfaces in exchange for $\mathrm{Ca}^{2+}$ and $\mathrm{M}^{+}$in the soil solution. Divalent $\mathrm{Ca}^{2+}$ will be preferentially sorbed over monovalent $\mathrm{M}^{+}$, and the relative proportions of each in the exchange complex and in solution will change such that the ratio $\left[\mathrm{M}^{+}\right] / \sqrt{\left[\mathrm{Ca}^{2+}\right]}$ in solution tends to be buffered. Hence the relative decrease in $\left[\mathrm{Ca}^{2+}\right]$ in solution will be greater than the relative decrease in $\left[\mathrm{M}^{+}\right]$. This effect will be smaller at longer times because exchangeable $\mathrm{Ca}^{2+}$ in the precipitation zone is increasingly removed as $\mathrm{CaCO}_{3}$. In the early stages, $\mathrm{CaCO}_{3}$ precipitation is relatively unimportant: the amount of $\mathrm{CaCO}_{3}$ precipitated close to the resin after 1 day is $<5 \mathrm{mmol} \mathrm{kg}^{-1}$ (Fig. 2E), whereas, from the $\mathrm{pH}$ change close to the resin (approx. 2 units) multiplied by $b_{\mathrm{HS}}$, the increase in $\mathrm{Ca}^{2+}+\mathrm{M}^{+}$ sorption due to reaction of $\mathrm{HCO}_{3}{ }^{-}$with the soil is approx. $30 \mathrm{mmol}_{\mathrm{C}} \mathrm{kg}^{-1}$. The discrepancy with the model is therefore less at longer times. It would be possible to allow for these effects in the model with suitable cation exchange relations. However this would mean creating additional model parameters and would unduly complicate the model.

Note the predicted Ca concentration in solution close to the resin increases over time. This is because the predicted $\mathrm{pH}$ decreases (see above), and with it the concentration of $\mathrm{HCO}_{3}{ }^{-}$in solution, balancing $\mathrm{Ca}^{2+}$, decreases.

$\mathrm{CaCO}_{3}$. The predicted precipitation of $\mathrm{CaCO}_{3}$ after 5 days agrees with the observed precipitation reasonably well (Fig. 2F). The precipitation after 1 day (Fig. 2E) is over predicted, presumably because of the over-prediction of $\left[\mathrm{Ca}^{2+}\right]$ discussed above.

ESEM-EDXA of the experimental residues showed that $\mathrm{CaCO}_{3}$ had formed on the nylon mesh separating the soil from the resin and in the first $2 \mathrm{~mm}$ of soil away from the resin. In particular, 
it was concentrated at the interface between the nylon mesh and the soil. XRD analysis confirmed that this carbonate mineralisation predominantly comprised calcite with some aragonite. Within the soil matrix the calcite consisted of disseminated very fine grained $(<2 \mu \mathrm{m})$ equant, subhedral rhombic to rounded grains. However, the $\mathrm{CaCO}_{3}$ formed on the nylon mesh displayed much more complex spherulitic growth fabrics. Crystallization appears to show a sequence of morphological changes from: (i) initial unidirectional-growth of low-angle radiating acicular (fibrous) crystallites forming "bow-tie" or "dumbbell-like" polycrystalline aggregates; (ii) progressive growth of the "dumbbell" aggregates to form larger, denser "dumbbells" and eventually spherical aggregates, and finally; (iii) replacement and recrystallization of the spherical aggregates of acicular crystals to form single coarser equant rhombic calcite crystals. This evolutionary sequence closely resembles the morphological changes observed in the nucleation of vaterite or amorphous $\mathrm{CaCO}_{3}$ (ACC) and their transformation to calcite (e.g. Meldrum and Hyde, 2001; Nissenbaum et al., 2008; Andreassen et al., 2010; Rodriguez-Blanco et al., 2011; 2012). This may indicate that in the region of the nylon mesh, where the degree of super-saturation of the solution was greatest, the more stable polymorph calcite (and minor aragonite) replaced or recrystallised from an initial rapidly-formed vaterite or ACC. At the circumneutral $\mathrm{pH}$ of the experiments, it is possible that a precursor ACC would have transformed directly to calcite, since other studies have shown that the transformation of ACC to vaterite is favoured by higher $\mathrm{pH}$ (Rodriguez-Blanco et al., 2012). The morphological variations in the $\mathrm{CaCO}_{3}$ precipitates may reflect the degree of supersaturation, and / or the availability of other cations such as $\mathrm{Mg}^{2+} . \mathrm{Mg}$ increases the stability of ACC and favours the formation of calcite over vaterite (RodriguezBlanco et al., 2012). Soluble organic compounds and lowser supersaturation can also favour the formation of "dumbbell-like" $\mathrm{CaCO}_{3}$ aggregates and inhibit formation of more spheroidal crystal aggregates (cf. Meldrum and Hyde, 2001; Andreassen et al., 2010). Inskeep and Bloom (1986b) found spherulitic clusters of calcite in pedogenic calcite, and concluded that in the presence of soluble organic matter that strongly inhibits crystal growth, the size of the crystallites is inhibited and continual re-nucleation is needed to precipitate further carbonate. Differences in the surface properties of the mesh compared with soil particles may also be important in encouraging nucleation and precipitation.

We conclude from the generally good agreement between the experimental and calculated results that the model satisfactorily describes the important processes.

\subsubsection{The rate of precipitation}

We compare our measured empirical rate constant with rate constants found in simple solution systems seeded with calcite as follows. Inskeep and Bloom (1986a) measured rates of calcite precipitation in seeded solutions with and without soluble soil organic ligands, and the rate of precipitation per unit solution volume $\left(R^{*}\right)$ fitted the equation $R^{*}=k_{\mathrm{f}} s K_{\mathrm{SP}}(\Omega-1)$ where $k_{\mathrm{f}}$ is a rate constant and $s$ the surface area of seed crystals per unit solution volume. The value of $k_{\mathrm{f}}$ in the absence of organic ligands was $1.17 \mathrm{dm}^{6} \mathrm{~mol}^{-1} \mathrm{~s}^{-1}$ with $s=200 \mathrm{dm}^{2}$ (seed crystals) $\mathrm{dm}^{-3}$ (solution). Hence, comparing with Eq. (17), the equivalent rate constant on a solution volume basis is $\alpha^{*}=k_{\mathrm{f}} s K_{\mathrm{SP}}=7.75 \times 10^{-7} \mathrm{~mol} \mathrm{dm}^{-3}$ (solution) $\mathrm{s}^{-1}$. In our experimental system, $\alpha^{*}=\alpha / \theta=9 \times 10^{-10} \mathrm{~mol} \mathrm{dm}{ }^{-3}$ (solution) $\mathrm{s}^{-1}$, i.e. three order of magnitude smaller. However, Inskeep and Bloom (1986a) found $k_{\mathrm{f}}$ decreased to zero with addition of water-soluble soil organic matter at $0.15 \mathrm{mM}$. The soil solution DOC concentration (operationally defined as OC passing 
through a $0.22-\mu \mathrm{m}$ filter) in our soil was several $\mathrm{mM}$. So our low precipitation rate is consistent with inhibition by DOC.

Other authors have found similar degrees of inhibition of calcite precipitation by DOC in natural systems (Lebron and Suarez, 1996, 1998; Hoch et al., 2000; Lin et al., 2005), and also by dissolved phosphate (Mucci, 1986; Paquette et al., 1986; Dove and Hochella, 1993) and Mg

(Nielsen et al., 2013). Dissolved phosphate and Mg concentrations in our soil were $<0.1 \mu \mathrm{M}$, which is below values causing inhibition. The mechanisms of inhibition by DOC involve adsorption of DOC on nucleation surfaces, and the degree of adsorption and resulting inhibition depend on the nature of the DOC and the solution composition (Inskeep and Bloom, 1986a; Lin et al., 2005). Values of DOC of a few mM are typical of mineral soils under natural or seminatural vegetation, depending on the soil organic matter content, clay content, $\mathrm{pH}$ and other factors (Moore, 1997; Buckingham et al., 2008). So some degree of inhibition of calcite precipitation by DOC is likely in most soils.

\subsection{Sensitivity analysis A: for the experimental system in planar geometry}

Here we analyse the sensitivity of the model to its input parameters to assess the importance of the various processes described, and to see if any of the processes can be ignored to simplify the model. Figure 3 shows how the amount and spread of $\mathrm{CaCO}_{3}$ precipitated in the region of the resin-soil boundary, and the $\mathrm{pH}$ change at the resin-soil boundary, vary with the model parameter values. The following effects are shown.

\subsubsection{Initial $\mathrm{pH}$ and $\mathrm{pH}$ buffer power}

The amount of $\mathrm{CaCO}_{3}$ precipitated and the spread of the precipitation zone increase strongly with the initial $\mathrm{pH}$ in the range $\mathrm{pH} 5$ to 8 (Figs $3 \mathrm{~A}$ and $\mathrm{B}$ ). However the $\mathrm{pH}$ at the resin-soil boundary is not much influenced by the initial $\mathrm{pH}$ (Fig. 3C). The explanation is that in the precipitation zone, close to the resin, the soil solution is saturated with respect to $\mathrm{CaCO}_{3}$ and the solution $\mathrm{pH}$ is controlled by the $\mathrm{CO}_{2}$ pressure, which is constant, and $\left[\mathrm{Ca}^{2+}\right]$, which is nearly constant following its initial decrease. The spread of the precipitation zone, and hence the total amount precipitated, increase with $\mathrm{pH}$ as the soil acidity diffusion coefficient increases (see Eq. 14). Likewise, the spread and amount of precipitation increase as the soil $\mathrm{pH}$ buffer power $b_{\mathrm{HS}}$ decreases (see Eq. 14).

\subsection{2 $\mathrm{CO}_{2}$ pressure}

The effect of $\mathrm{CO}_{2}$ pressure is complicated. An increase in $\mathrm{CO}_{2}$ pressure will reduce the $\mathrm{pH}$ required for $\mathrm{CaCO}_{3}$ saturation, but it will also increase the rate of diffusion of acidity through the soil (Eq. 14), and hence tend to disperse $\mathrm{HCO}_{3}{ }^{-}$into the soil away from the resin. Hence, as the $\mathrm{CO}_{2}$ pressure increases in Fig. 3, the amount of $\mathrm{CaCO}_{3}$ precipitated decreases slightly, the spread of the precipitation zone increases, and the $\mathrm{pH}$ rise near the resin decreases.

\subsubsection{Initial salt concentration}

The amount of $\mathrm{CaCO}_{3}$ precipitated increases strongly as $\left[\mathrm{Cl}^{-}\right]_{\text {initial }}$ increases both because $\left[\mathrm{Ca}^{2+}\right]$ tends to increase, and because the flux of $\mathrm{Cl}^{-}$towards the resin increases and therefore the flux of $\mathrm{HCO}_{3}{ }^{-}$from the resin also increases. The spread of the precipitation zone changes very non-linearly with $\left[\mathrm{Cl}^{-}\right]_{\text {initial }}$, decreasing slightly above and sharply below the standard value in Fig. 3. Evidently as $\left[\mathrm{Cl}^{-}\right]_{\text {initial }}$ increases above the standard value, diffusion of $\mathrm{Ca}^{2+}$ with $\mathrm{Cl}^{-}$ towards the resin exceeds its consumption in $\mathrm{CaCO}_{3}$ precipitation, and so precipitation occurs increasingly close to the resin and the spread of precipitation decreases. Whereas below the 
standard $\left[\mathrm{Cl}^{-}\right]_{\text {initial }}$ value, $\mathrm{CaCl}_{2}$ diffusion increasingly limits precipitation, and, as the amount of precipitation tends to zero, the spread necessarily tends to zero.

\subsubsection{Soil water content}

The sensitivity analysis shows that the amount of $\mathrm{CaCO}_{3}$ precipitated and the spread of precipitation away from the resin are sensitive to the soil water content and diffusion impedance factor, $\theta$. This is because as $\theta f$ decreases, the rate of supply of reactants into the precipitation zone is increasingly limiting. Note we have made our calculations at constant initial salt concentration, represented by $\left[\mathrm{Cl}^{-}\right]_{\text {initial }}$. In practice the salt concentration will tend to increase as a soil dries, and this will tend to increase the precipitation rate as shown by the model's sensitivity to $\left[\mathrm{Cl}^{-}\right]_{\text {initial }}$. Where drying is localised, for example around a plant root or a fungal hypha, the salt concentration will tend to increase locally but the supply of reactants from the moist soil further away will be maintained.

\subsubsection{Precipitation rate constant}

The amount of $\mathrm{CaCO}_{3}$ precipitated is relatively insensitive to changes in the precipitation rate constant $\alpha$. A 50-fold increase in $\alpha$ produced only a 50\% increase in the amount precipitated. Over the range of conditions considered, factors influencing the rates of delivery of reactants to and from the precipitation zone are at least as important as the precipitation kinetics. As $\alpha$ increases, precipitation is increasingly limited by diffusion of reactants in and the spread of the precipitation zone decreases.

The sensitivity of the model to its parameters, evident from this analysis, shows that the good agreement between the observed and predicted concentration-distance profiles is good evidence that the model is sound. The sensitivity analysis also shows that all the processes considered are important, and therefore a model at least as complicated as this is needed to adequately describe the system.

\subsection{Sensitivity analysis B: for practical applications in cylindrical geometry}

Having corroborated the basic model in planar geometry, we now illustrate its practical application. We use the model in cylindrical geometry to assess likely rates of $\mathrm{CaCO}_{3}$ precipitation near a plant root or a soil macro-pore containing urea. We derive a realistic range in fluxes of base into the soil for these applications as follows.

For the region around a plant root, the flux of base depends on the net intake of anions (principally $\mathrm{NO}_{3}{ }^{-}, \mathrm{H}_{2} \mathrm{PO}_{4}^{-}, \mathrm{SO}_{4}{ }^{2-}, \mathrm{Cl}^{-}$) compared with cations $\left(\mathrm{NH}_{4}{ }^{+}, \mathrm{K}^{+}, \mathrm{Na}^{+}, \mathrm{Ca}^{2+}, \mathrm{Mg}^{2+}\right.$ ), and the resulting release of $\mathrm{H}^{+}$or $\mathrm{HCO}_{3}{ }^{-}$to maintain electrical neutrality across the root-soil boundary (Nye, 1981; Hinsinger, 2003; Neumann and Römheld, 2012). Plants absorbing nitrogen as $\mathrm{NH}_{4}{ }^{+}$ or $\mathrm{N}_{2}$ tend to lower the rhizosphere $\mathrm{pH}$; those absorbing nitrogen as $\mathrm{NO}_{3}{ }^{-}$raise it. Nye (1981) estimates a flux of $\mathrm{HCO}_{3}{ }^{-}$for common plant species growing well in soil and absorbing nitrogen as $\mathrm{NO}_{3}{ }^{-}$of $3 \times 10^{-10} \mathrm{~mol} \mathrm{dm}^{-2}$ (root surface) $\mathrm{s}^{-1}$. We take this as the lower end of the range we consider.

For the upper end we consider the flux of base from a macro-pore containing a high concentration of urea in the soil solution. The urea diffuses into the surrounding soil pore network where it is rapidly hydrolysed producing $\mathrm{NH}_{4}{ }^{+}$and $\mathrm{HCO}_{3}{ }^{-}$. For a large macro-pore, and rate of hydrolysis proportional to the urea concentration (e.g. Tobler et al., 2011), the steady-state 
flux of urea into the soil is approximately (Crank, 1975, Eq. 4.50): $F_{\mathrm{U}}=[\mathrm{urea}]_{0} \sqrt{D_{\mathrm{U}} k}$ where [urea $]_{0}$ is the concentration in the macro-pore, $D_{\mathrm{U}}$ the urea diffusion coefficient in the soil and $k$ the hydrolysis rate constant. From the reaction stoichiometry $\left(\mathrm{CO}\left(\mathrm{NH}_{2}\right)_{2}+\mathrm{CO}_{2}+3 \mathrm{H}_{2} \mathrm{O}=2 \mathrm{NH}_{4}^{+}\right.$ $\left.+2 \mathrm{HCO}_{3}{ }^{-}\right), F_{\mathrm{B}}=2 \mathrm{~F}_{\mathrm{U}}$. A realistic range of $k$ values is $10^{-7}$ to $10^{-5} \mathrm{~s}^{-1}$ (Rachhpal-Sigh and Nye, 1986) and $D_{\mathrm{U}}=D_{\mathrm{LU}} \theta f$ (Rachhpal-Singh and Nye, 1986) $=2 \times 10^{-9} \mathrm{dm}^{2} \mathrm{~s}^{-1}$ for $\theta f=0.02$. So for [urea $]_{0}=0.1 \mathrm{M}$, an upper value for $F_{\mathrm{B}}$ is $10^{-8} \mathrm{~mol} \mathrm{dm} \mathrm{dm}^{-2} \mathrm{~s}^{-1}$.

Figure 4 shows how $\mathrm{CaCO}_{3}$ precipitation varies over this range in $F_{\mathrm{B}}$ values for different $\mathrm{pHs}$ and values of the key soil variables, and Fig. 5 shows the corresponding values of the $\mathrm{pH}$ at the root or macro-pore surface $r=a$. The value of $a$ and $b$ used are realistic for a graminaceous root system, or for transmission pores in a well-structured soil. The following effects are apparent.

\subsection{1. $p H$ buffer power}

Figures $4 \mathrm{~A}-\mathrm{C}$ and $5 \mathrm{~A}-\mathrm{C}$ show the effect of $b_{\mathrm{HS}}$. The low $b_{\mathrm{HS}}$ value is typical of sandy soils; the high value is typical of more clayey soils. At low values, a given flux of acidity produces a larger $\mathrm{pH}$ increase, and therefore a greater rate of precipitation, depending on the initial $\mathrm{pH}$. For initial $\mathrm{pH}=5$, a 10 -fold decrease in $b_{\mathrm{HS}}$ increases precipitation roughly 10 -fold, whereas at $\mathrm{pH} 7$ the increase is only five-fold. Figure $5 \mathrm{~A}-\mathrm{C}$ shows that $b_{\mathrm{HS}}$ has relatively little influence on the $\mathrm{pH}$ at the root or macro-pore surface for a given flux of base; its main influence is on the spread of $\mathrm{HCO}_{3}{ }^{-}$and hence precipitation through the soil, due to its effect on the soil acidity diffusion coefficient (Eq. 14). The $\mathrm{pH}$ at $r=a$ increases steeply with $F_{\mathrm{HS}}$ at $F_{\mathrm{HS}}$ values too small to saturate the soil with respect to $\mathrm{CaCO}_{3}$; the increase is much more gradual at $F_{\mathrm{HS}}$ values sufficient to produce saturation. Little or no $\mathrm{CaCO}_{3}$ precipitation is predicted for $F_{\mathrm{HS}}$ values typical of plant roots, except at initial $\mathrm{pH}=7$ where the soil solution is in any case close to saturation (the $\mathrm{pH}$ of soil in equilibrium with calcite at $P_{\mathrm{CO} 2}=0.5 \mathrm{kPa}$ and $\left[\mathrm{Ca}^{2+}\right]=10 \mathrm{mM}$ is 7.1). At greater $F_{\mathrm{HS}}$ values the precipitation increases near exponentially with $F_{\mathrm{HS}}$. Hence, in a urea-amended soil, the precipitation rate will be sensitive to the rate of urea hydrolysis.

\subsection{2. $\mathrm{CO}_{2}$ pressure}

The range in $P_{\mathrm{CO} 2}$ in Figs $4 \mathrm{D}-\mathrm{F}$ and $5 \mathrm{D}-\mathrm{F}$ is from near atmospheric to values typical of wet soils, where respiratory $\mathrm{CO}_{2}$ accumulates because of the reduced air-filled porosity. As in the planar model, the effects of $P_{\mathrm{CO} 2}$ are complicated. An increase will reduce the $\mathrm{pH}$ required for $\mathrm{CaCO}_{3}$ saturation but it will also tend to disperse $\mathrm{HCO}_{3}{ }^{-}$away from the precipitation zone. Hence an increase in $P_{\mathrm{CO} 2}$ at initial $\mathrm{pHs} 5$ and 6 decreases the $\mathrm{pH}$ required for saturation, as shown by the smaller $\mathrm{pH}$ at $r=a$ at high $F_{\mathrm{B}}$ in Fig. 5D-E; but it also decreases the total amount of $\mathrm{CaCO}_{3}$ precipitated because of the effect on $\mathrm{HCO}_{3}{ }^{-}$dispersion (Fig. 4D-E). However, at initial $\mathrm{pH}=7$ and high $P_{\mathrm{CO} 2}$, soil base diffusion is sufficiently fast that $\mathrm{HCO}_{3}{ }^{-}$spreads through the soil as far as the outer boundary $r=b$ where it is 'reflected back' and accumulates. The $\mathrm{pH}$ increase spreads correspondingly far through the soil and the overall precipitation is correspondingly greater. This effect will depend on the geometry of the system and the distance between adjacent roots or macro-pores, as it determines the value of $b$. The $\mathrm{CO}_{2}$ effect will therefore increase with increasing root or pore length-density per unit soil volume.

\subsubsection{Precipitation rate constant}


Figure 4G-I show the effect of a 10-fold variation in $\alpha$. The intermediate value is comparable to that in our experiments; the low and high values are within the range expected for different soils based on the literature discussed in Section 4.1.3. The results show that precipitation is sensitive to $\alpha$ over the range considered. The smaller the value, the greater the flux of base required for a given degree of precipitation. However the relation is non-linear: a five-fold increase in $\alpha$ from 0.1 to $0.5 \mathrm{nmol} \mathrm{dm}^{-3} \mathrm{~s}^{-1}$ produced a roughly three-fold increase in precipitation, whereas a two-fold increase from 0.5 to $1 \mathrm{nmol} \mathrm{dm}{ }^{-3} \mathrm{~s}^{-1}$ produced only a roughly 0.5 -fold increase in precipitation. The effect of $\alpha$ on the pH at $r=a$ (Fig. 5G-I) is only seen at high initial $\mathrm{pH}$ where rates of $\mathrm{HCO}_{3}{ }^{-}$consumption and $\mathrm{H}^{+}$production in $\mathrm{CaCO}_{3}$ precipitation are sufficiently large.

Some implications of these findings for practical applications are as follows. As far as acidbase changes around plants roots are concerned, the important considerations are the $\mathrm{pH}$ and $\mathrm{CaCO}_{3}$ formation at or near the root surface as these determine the solubility and hence root access of nutrients and pollutants. It is important to be able to model these accurately because of the difficulties in measuring them. The sensitivity analysis shows that for typical fluxes of base from roots, it is unlikely that any $\mathrm{CaCO}_{3}$ precipitation will be induced, except at $\mathrm{pHs}$ greater than 7 where the soil solution will in any case be close to saturation.

For the fate of urea in soil, and resulting losses of nitrogen by $\mathrm{NH}_{3}$ volatilization, it is the $\mathrm{pH}$ in the zone of urea hydrolysis that is important. The model shows that, where rates of $\mathrm{CaCO}_{3}$ precipitation are sufficient, the $\mathrm{pH}$ rise in the zone of urea hydrolysis will in many cases be impeded by $\mathrm{CaCO}_{3}$ precipitation, and this will lessen $\mathrm{NH}_{3}$ losses. For a discussion and model of this system in the absence of $\mathrm{CaCO}_{3}$ precipitation, see the series of papers by Rachhpal-Singh and Nye (1986) and Kirk and Nye (1991).

For applications in which the objective is to physically block pores or cement soil by $\mathrm{CaCO}_{3}$ precipitation, it is the spread of the zone of precipitation away from the source of base that is important. Here the sensitivity analysis shows the importance of the initial soil $\mathrm{pH}$, the soil $\mathrm{pH}$ buffer power and the $\mathrm{CO}_{2}$ pressure. A wide spread of precipitation is favoured by small $\mathrm{pH}$ buffer power, as in sandy soils or sub-strata, or high $\mathrm{CO}_{2}$ pressures. The latter situation could arise locally in any soils where there is high biological activity and particularly where water-filled pores are present and curtail the diffusion of $\mathrm{CO}_{2}$. The analysis also shows the importance of the system geometry and the spacing between neighbouring macro-pores into which base is introduced.

\section{CONCLUSIONS}

The model presented satisfactorily predicts the profiles of reactants and the $\mathrm{CaCO}_{3}$ precipitated in $\mathrm{Ca}^{2+}$-saturated soil near a source of base. The model uses only independently determined parameters and makes no arbitrary assumptions. Hence the good agreement between observed and predicted results suggests the important processes are correctly described in the model.

The sensitivity analysis shows that, over realistic ranges of parameter values, the amount precipitated and spread of the precipitation zone are sensitive to the parameters controlling rates of reactant transport to and from the precipitation zone, as well as to the empirical precipitation rate constant. The sensitivity to transport indicates that any simpler treatment of calcite formation in soil, not allowing for transport limitations, would be inadequate. The sensitivity analysis also shows that the importance of the different model variables varies between model applications. 


\section{ACKNOWLEDGEMENTS}

AV was funded by studentships from the UK Engineering and Physical Sciences Research Council (EPSRC) Doctoral Training Account at Cranfield and the British Geological Survey (BGS) University Funding Initiative. We thank Simon Kemp of BGS for help with the XRD analysis. AEM publishes with the permission of the Executive Director of the British Geological Survey (NERC).

\section{APPENDIX: $\mathrm{CO}_{2}$ GRADIENT IN THE SOIL AIR}

In our treatment of acid-base transfer in the model, we assume that the $\mathrm{CO}_{2}$ partial pressure in the soil air is constant across the zone of $\mathrm{pH}$ change. The following calculations show that this is realistic for our experimental conditions over the relevant range of $\mathrm{CO}_{2}$ generation in the soil.

In the experiments, moist soil was incubated in $0.3 \mathrm{dm}$ long cylinders with the $\mathrm{HCO}_{3}{ }^{-}$-resin end sealed to the atmosphere and the other end open. If the rate of $\mathrm{CO}_{2}$ generation in excess of its removal in $\mathrm{CaCO}_{3}$ precipitation is $M_{\mathrm{C}}$ mol per unit soil volume per unit time, and if a steady state exists in which the net rate of $\mathrm{CO}_{2}$ generation in the soil equals its rate of loss from the open end of the cylinder, then

$$
V M_{\mathrm{C}}=-A D \frac{\mathrm{d} C_{\mathrm{g}}}{\mathrm{d} x}
$$

where $V=$ volume of soil cylinder, $A=$ cross-sectional area of cylinder, $x=$ distance from resin end, $D=$ diffusion coefficient of $\mathrm{CO}_{2}$ through the soil and $C_{\mathrm{g}}=\mathrm{CO}_{2}$ concentration in the gas phase. Rearranging, integrating and inserting the boundary condition $C_{\mathrm{g}}=C_{\mathrm{ga}}$ at $x=L$, gives for the $\mathrm{CO}_{2}$ concentration at any distance $x$ into the soil:

$$
C_{\mathrm{g}}=C_{\mathrm{g}_{\mathrm{a}}}+\frac{M_{\mathrm{C}}(L-x)^{2}}{D}
$$

Diffusion in the liquid phase will be negligible compared with the gas phase, so $D=D_{\mathrm{g}} \theta_{\mathrm{g}} f_{\mathrm{g}}$ where $D_{\mathrm{g}}=\mathrm{CO}_{2}$ diffusion coefficient in air, $\theta_{\mathrm{g}}=$ volumetric soil air content $\left(=1-\left(\rho / \rho_{\mathrm{p}}\right)-\theta\right.$ where $\rho_{\mathrm{p}}=$ particle density $=2.65 \mathrm{~kg} \mathrm{dm}^{-3}$ ) and $f_{\mathrm{g}}=$ impedance factor for the gaseous pathway. $D_{\mathrm{g}}$ for $\mathrm{CO}_{2}$ in air at $25{ }^{\circ} \mathrm{C}=1.55 \times 10^{-3} \mathrm{dm}^{2} \mathrm{~s}^{-1}$. For our experimental soil under the conditions of our experiment, $\theta_{\mathrm{g}}=0.11$. So if $f_{\mathrm{g}}=\theta_{\mathrm{g}}, D=6.2 \times 10^{-4} \mathrm{dm}^{2} \mathrm{~s}^{-1}$.

Figure A1 gives calculations with Eq. (A.1) and these parameter values for a realistic range of $M_{\mathrm{C}}$ values. It shows that $P_{\mathrm{CO}_{2}}$ is roughly constant over the depth of soil where there is a $\mathrm{pH}$ gradient in our experimental columns (0-10 mm), as assumed in the model.

\section{REFERENCES}

Amrhein C., Zahow M.F. and Suarez D.L. (1993) Calcite supersaturation in soil suspensions. Soil Sci. 156, 163-170. 
Andreassen, J.-P., Flaten, E.M., Beck, R. and Lewis, A.E. (2010) Investigations of spherulitic growth in industrial crystallization. Chemical Engineering Research and Design, 88, 11631168.

Buckingham S., Tipping E. and Hamilton-Taylor J. (2008) Dissolved organic carbon in soil solutions: a comparison of collection methods. Soil Use Manage. 24, 29-36.

Chu J., Stabnikov V. and Ivanov V. (2012) Microbially induced calcium carbonate precipitation on surface or in the bulk of soil. Geomicrobiol. J. 29, 544-549.

Corstanje R., Kirk G.J.D., Pawlett M., Read R. and Lark R.M. (2008) Spatial variation of ammonia volatilization from soil and its scale dependent correlation with soil properties. Eur. J. Soil Sci. 59, 1260-1270.

Cunningham B., Gerlach R., Spangler L. and Mitchell A.C. (2009) Microbially enhanced geologic containment of sequestered supercritical $\mathrm{CO}_{2}$. Energy Procedia 1, 3245-3252.

Crank, J. (1975) The Mathematics of Diffusion. Oxford University Press, Oxford.

Dove P.M. and Hochella M.F. (1993) Calcite precipitation mechanisms and inhibition by orthophosphate: In situ observations by Scanning Force Microscopy. Geochim. Cosmochim. Acta 57, 705-714.

Dupraz S., Parmentiera M., Méneza B. and Guyota F. (2009) Experimental and numerical modeling of bacterially induced $\mathrm{pH}$ increase and calcite precipitation in saline aquifers. Chem. Geol. 265, 44-53.

Ferris F.G., Stehmeier L.G., Kantzas A. and Mourits F.M. (1996) Bacteriogenic mineral plugging. J. Can. Petrol. Technol. 13, 57-67.

Fujita Y., Taylor J.L., Wendt L.M., Reed D.W. and Smith R.W. (2010) Evaluating the potential of native ureolytic microbes to remediate a ${ }^{90} \mathrm{Sr}$ contaminated environment. Environ. Sci. Technol. 44, 7652-7658.

Gustafsson, J.P. (2012) Visual MINTEQ Version 3.0. KTH, Stockholm, Sweden.

Hinsinger P., Plassard C., Tang C.X. and Jaillard B. (2003) Origins of root-mediated pH changes in the rhizosphere and their responses to environmental constraints: A review. Plant Soil 248, 43-59.

Hoch A.R., Reddy M.M. and Aiken G.R. (2000) Calcite crystal growth inhibition by humic substances with emphasis on hydrophobic acids from the Florida Everglades. Geochim. Cosmochim. Acta 64, 61-72.

Inskeep W.P. and Bloom P.R. (1986a) Kinetics of calcite precipitation in the presence of watersoluble organic ligands. Soil Sci. Soc. Am. Proc. 50, 1167-1172.

Inskeep W.P. and Bloom P.R. (1986b) Calcium carbonate supersaturation in soil solutions of calciaquolls. Soil Sci. Soc. Am. Proc. 50, 1431-1437.

Kirk G.J.D. (2004) The Biogeochemistry of Submerged Soils. Wiley, Chichester.

Kirk G.J.D. and Nye P.H. (1991) A model of ammonia volatilization from applied urea. VI. The effects of transient state water movement. J. Soil Sci. 42, 115-125.

Lebron I. and Suarez D.L. (1996) Calcite nucleation and precipitation kinetics as affected by dissolved organic matter at $25^{\circ} \mathrm{C}$ and $\mathrm{pH}$ 7.5. Geochim. Cosmochim. Acta 60, 2765-2776. 
Lebron I. and Suarez D.L. (1998) Kinetics and mechanisms of precipitation of calcite as affected by $P_{\mathrm{CO} 2}$ and organic ligands at $25^{\circ} \mathrm{C}$. Geochim. Cosmochim. Acta 62, 405-416.

Lin Y.P., Singer P.C. and Aiken G.R. (2005) Inhibition of calcite precipitation by natural organic material: kinetics, mechanisms, and thermodynamics. Environ. Sci. Technol. 39, 6420-6428.

Meldrum, F.C. and Hyde, S.T. (2001) Morphological influence of magnesium and organic additives on the precipitation of calcite J. Crystal Growth, 231, 544-558.

Mitchell A.C. and Ferris F.G. (2005) The coprecipitation into calcite precipitates induced by bacterial artificial groundwater: temperature and kinetic Geochim. Cosmochim. Acta 69, 41994210.

Mitchell A.C., Dideriksen K., Spangler L.H., Cunningham A.B. and Gerlach R. (2010) Microbially enhanced carbon capture and storage by mineral-trapping and solubility-trapping. Environ. Sci. Technol. 44, 5270-5276.

Moore T.R. (1997) Dissolved organic carbon: sources, sinks, and fluxes and role in the soil carbon cycle. In: Soil Processes and the Carbon Cycle (eds R. Lal, J.M. Kimble, R.F. Follett \& B.A. Stewart). CRC Press LLC, Boca Raton, FL, pp. 281-292.

Morse J.W., Arvidson R.S. and Lüttge A. (2007) Calcium carbonate formation and dissolution. Chem. Rev. 107, 342-391.

Mucci A. (1986) Growth kinetics and composition of magnesian calcite overgrowths precipitated from seawater: Quantitative influence of orthophosphate ions. Geochim. Cosmochim. Acta 50, 2255-2265.

Neumann G. and Römheld V. (2012) Rhizosphere chemistry in relation to plant nutrition. In: Marschner's Mineral Nutrition of Higher Plants. $3^{\text {rd }}$ edn (ed. P Marschner). Academic Press, Lodnon, pp. 347-368.

Nielsen L.C., De Yoreo J.J. and De Paolo D.J. (2013) General model for calcite growth kinetics in the presence of impurity ions. Geochim. Cosmochim. Acta 115, 100-114.

Nissenbaum, J., Stipp, S.L.S. and Johnnson, A. (2008) Transformation of calcium carbonate polymorphs: preliminary results Mineralogical Magazine, 72, 473-476.

Nye P.H. (1972) The measurement and mechanism of ion diffusion in soils. VIII. A theory for the propagation of changes of $\mathrm{pH}$ in soils. J. Soil Sci. 23, 82-92.

Nye P.H. (1981) Changes of pH across the rhizosphere induced by plant roots. Plant Soil 61, 726.

Paquette J., Vali H. and Mucci A. (1996) TEM study of Pt-C replicas of calcite overgrowths precipitated from electrolyte solutions. Geochim. Cosmochim. Acta 60, 4689-4699.

Plummer L.N. and Busenberg E. (1983) The solubilities of calcite, aragonite and vaterite in $\mathrm{CO}_{2}{ }^{-}$ $\mathrm{H}_{2} \mathrm{O}$ solutions between $0{ }^{\circ} \mathrm{C}$ and $90{ }^{\circ} \mathrm{C}$, and an evaluation of the aqueous model for the system $\mathrm{CaCO}_{3}-\mathrm{CO}_{2}-\mathrm{H}_{2} \mathrm{O}$. Geochim. Cosmochim. Acta 46, 1011-1040.

Ptashnyk M., Roose T. and Kirk G.J.D. (2010) Diffusion of strongly-sorbed solutes in soil: a dual porosity model allowing for slow access to sorption sites and time-dependent sorption reactions. Eur. J. Soil Sci. 61, 108-119. 
Rachhpal-Singh and Nye P.H. (1986) A model of ammonia volatilization from applied urea. I. Development of the model. J. Soil Sci. 37, 9-20.

Renforth P., Manning D.A.C. and Lopez-Capel E. (2009) Carbonate precipitation in artificial soils as a sink for atmospheric carbon dioxide. Appl. Geochem. 24, 1757-1764.

Rodriguez-Blanco, J.D., Shaw, S., and Benning, L.G. (2011) The kinetics and mechanisms of amorphous calcium carbonate (ACC) crystallization to calcite, via vaterite. Nanoscale, $\mathbf{3}$, 265-271.

Rodriguez-Blanco J.D., Shaw S., Bots P., Roncal-Herrero T. and Benning L.G. (2012) The role of $\mathrm{pH}$ and $\mathrm{Mg}$ on the stability and crystallization of amorphous calcium carbonate. J. Alloys Compounds 536 (Supplement 1), S477-S479.

Sposito G. (2008) The Chemistry of Soils. $2^{\text {nd }}$ edn. Oxford University Press, Oxford.

Stocks-Fischer S., Galinat J.K. and Bang S.S. (1999) Microbiological precipitation of $\mathrm{CaCO}_{3}$. Soil Biol. Biochem. 31 1563-1571.

Stumm W. and Morgan J.J. (1996) Aquatic Chemistry. $3^{\text {rd }}$ edn. Wiley-Interscience, New York.

Tinker P.B. and Nye P.H. (2000) Solute Movement in the Rhizosphere. Oxford University Press, New York.

Tobler D.J., Cuthbert M.O. Greswell R.B., Riley M.S., Renshaw J.C., Handley-Sidhu S. and Phoenix V.R. (2011) Comparison of rates of ureolysis between Sporosarcina pasteurii and an indigenous groundwater community under conditions required to precipitate large volumes of calcite. Geochim. Cosmochim. Acta 75, 3290-3301.

Whitmore A.P., Kirk G.J.D. and Rawlins B.G. (2014) Technologies for increasing carbon storage in soil to mitigate climate change. Soil Use Manage., DOI: 10.1111/sum.12115.

Wolthers M., Nehrke G., Gustafsson J.P. and Van Cappellen P. (2012) Calcite growth kinetics: Modeling the effect of solution stoichiometry. Geochim. Cosmochim. Acta 77, 121-134. 
Table 1

Nomenclature.

\begin{tabular}{|c|c|c|}
\hline Symbol & Meaning & Units \\
\hline$a$ & radius of root or macro-pore & $\mathrm{dm}$ \\
\hline$b$ & radius of cylinder of influence of root or macro-pore & $\mathrm{dm}$ \\
\hline$b_{\mathrm{HS}}$ & soil pH buffer power, equal to $-\mathrm{d}[\mathrm{HS}] / \mathrm{dpH}$ & mol dm ${ }^{-3}$ (soil) $\mathrm{pH}^{-1}$ \\
\hline DOC & dissolved organic carbon & \\
\hline$D_{\mathrm{HS}}$ & soil acidity diffusion coefficient, defined by Eq. (15) & $\mathrm{dm}^{2} \mathrm{~s}^{-1}$ \\
\hline$D_{\mathrm{L}}$ & $\begin{array}{l}\text { diffusion coefficient in free solution, subscripted } \mathrm{Cl}_{\text {for }} \mathrm{Cl}^{-} \\
\text {, } \mathrm{H} \text { for } \mathrm{H}_{3} \mathrm{O}^{+}, \mathrm{B} \text { for } \mathrm{HCO}_{3}^{-}\end{array}$ & $\mathrm{dm}^{2} \mathrm{~s}^{-1}$ \\
\hline$F_{\mathrm{B}}$ & flux of $\mathrm{HCO}_{3}^{-}$ & $\mathrm{mol} \mathrm{dm} \mathrm{d}^{-2}$ \\
\hline$f$ & diffusion impedance factor & \\
\hline [HS] & concentration of titratable acidity in the soil & mol dm ${ }^{-3}$ (soil) \\
\hline IAP & ion activity product, $\left(\mathrm{Ca}^{2+}\right)\left(\mathrm{CO}_{3}{ }^{2-}\right)$ & $\mathrm{mol}^{2} \mathrm{dm}^{-6}$ (solution) \\
\hline [ion] & $\begin{array}{l}\text { concentration of ion in the soil solution where ion }=\mathrm{Ca}^{2+} \text {, } \\
\mathrm{CaHCO}_{3}{ }^{+}, \mathrm{M}^{+}, \mathrm{HCO}_{3}^{-}, \mathrm{CO}_{3}^{2-}, \mathrm{Cl}^{-}, \mathrm{H}_{3} \mathrm{O}^{+}\end{array}$ & mol dm ${ }^{-3}$ (solution) \\
\hline$K_{\mathrm{S}}$ & solubility of $\mathrm{CO}_{2}$ in water & mol dm ${ }^{-3}$ (solution) $\mathrm{kPa}^{-1}$ \\
\hline$K_{\mathrm{SP}}$ & solubility product of $\mathrm{CaCO}_{3}$ & $\mathrm{~mol}^{2} \mathrm{dm}^{-6}$ (solution) \\
\hline$K_{1}$ & apparent first dissociation constant of $\mathrm{H}_{2} \mathrm{CO}_{3}$ & mol dm ${ }^{-3}$ (solution) \\
\hline$L$ & length of soil column & $\mathrm{dm}$ \\
\hline$P_{\mathrm{CO}_{2}}$ & $\mathrm{CO}_{2}$ pressure in soil air & $\mathrm{kPa}$ \\
\hline$R$ & rate of $\mathrm{CaCO}_{3}$ precipitation per unit soil volume & mol dm ${ }^{-3}$ (soil) s ${ }^{-1}$ \\
\hline$R$ & radial distance & $\mathrm{dm}$ \\
\hline$t$ & Time & $\mathrm{s}$ \\
\hline$x$ & distance from AER surface $(x=0)$ & $\mathrm{dm}$ \\
\hline$\alpha$ & rate constant for $\mathrm{CaCO}_{3}$ precipitation, defined by Eq. (17) & mol dm ${ }^{-3}$ (soil) $\mathrm{s}^{-1}$ \\
\hline$\theta$ & volume fraction of soil water & $\mathrm{dm}^{3}$ (solution) $\mathrm{dm}^{-3}$ (soil) \\
\hline
\end{tabular}


$\Omega \quad$ saturation ratio ( $\left.{ }^{I A P} / K_{\mathrm{SP}}\right)$ 
B

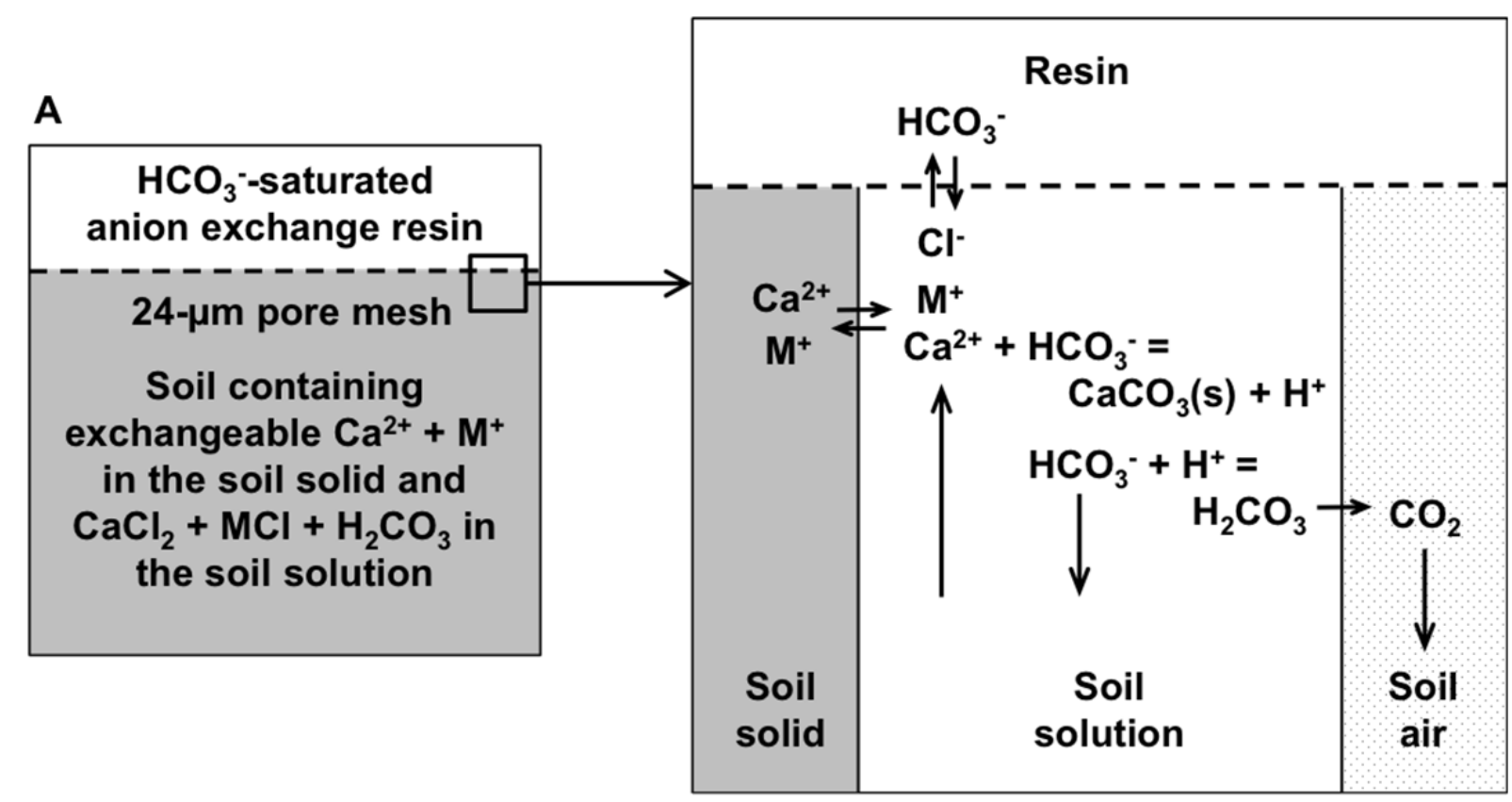

Fig. 1. (A) Schematic of the experimental system; (B) enlargement (not to scale) showing the reactions taking place. A moist layer of $\mathrm{HCO}_{3}^{-}$-saturated anion exchange resin is in contact with a column of moist soil with near neutral $\mathrm{pH}$ and containing $\mathrm{Ca}^{2+}$ and $\mathrm{M}^{+}$exchangeable cations and $\mathrm{CaCl}_{2}, \mathrm{MCl}$ and $\mathrm{H}_{2} \mathrm{CO}_{3}$ in the soil solution. In (B), the soil solid, solution and air are represented as parallel compartments in which transport and reaction occur. 

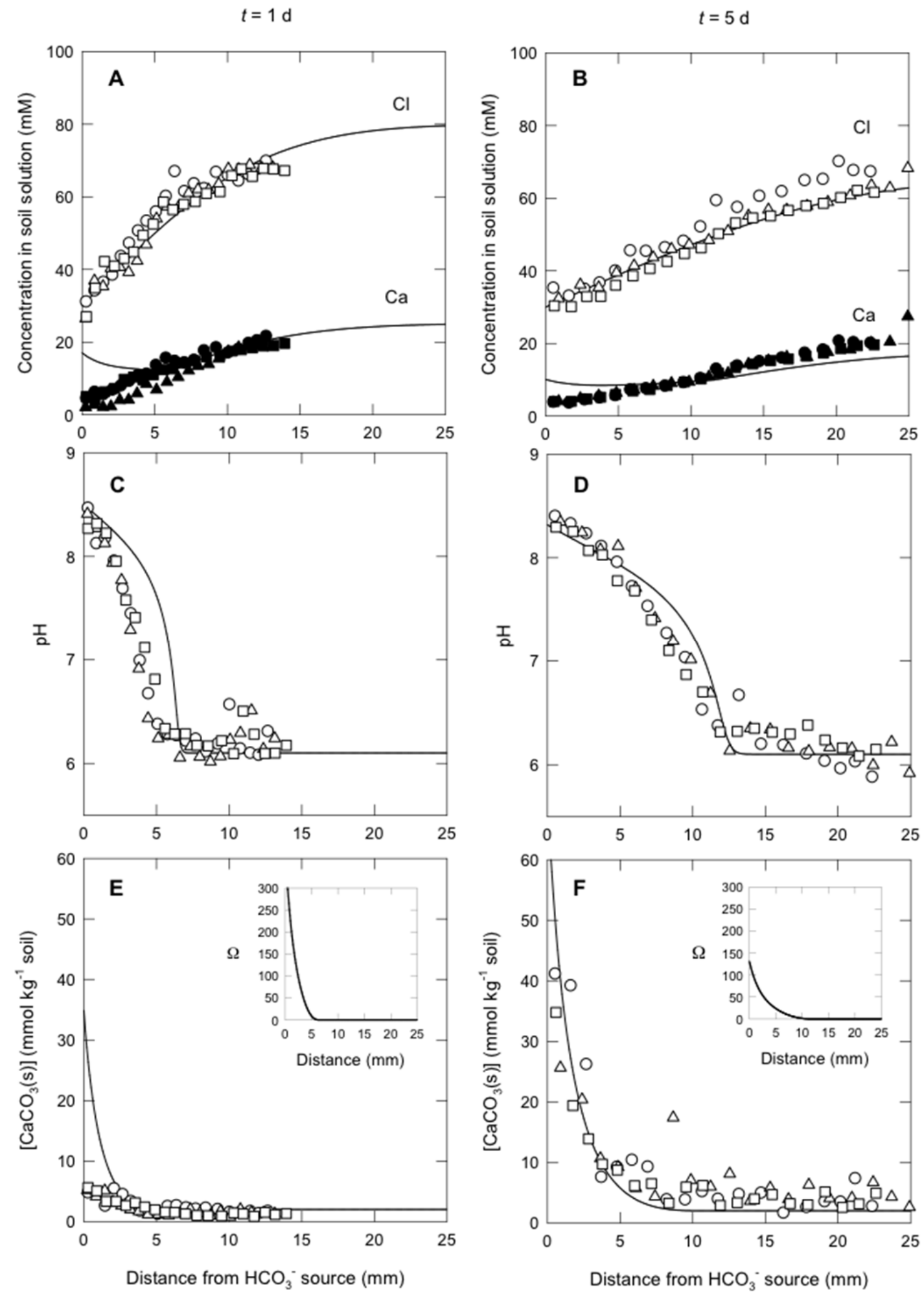

Fig. 2. Observed and calculated concentration profiles with distance from the resin-soil boundary. The points are the measured values (three replicates indicated with different symbols). The lines 
are the model predictions. The insets in the lower panels show the profiles of the calcite saturation ratio ( $\Omega=I A P / K_{\mathrm{SP}}$ ). 

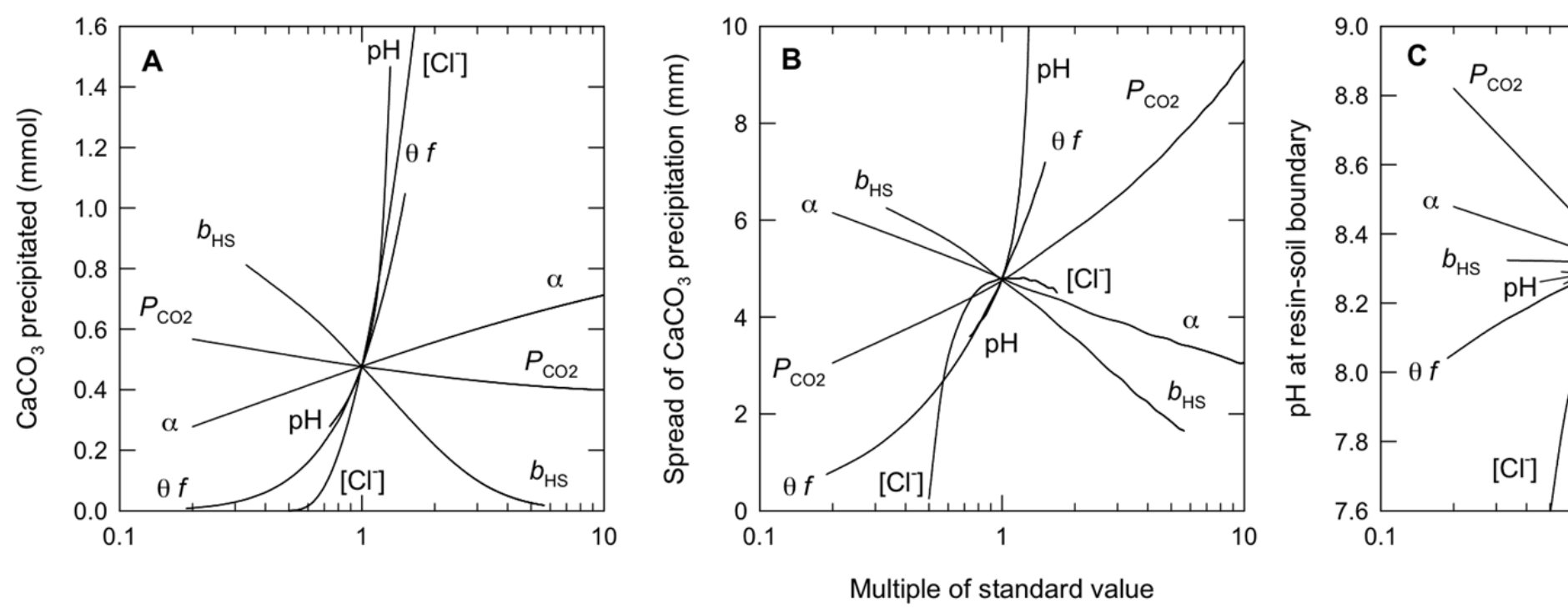

Fig. 3. Sensitivity analysis of the model in planar geometry. The output variables are: (A) the amount of $\mathrm{CaCO}_{3}$ precipitated in the soil column (obtained by numerical integration using Simpson's rule), (B) the spread of the $\mathrm{CaCO}_{3}$ precipitation zone (obtained from the distance at which $\left[\mathrm{CaCO}_{3}(\mathrm{~s})\right]$ falls to $5 \%$ of the value at the resin-soil boundary) and (C) the $\mathrm{pH}$ at the resin-soil boundary. Each of the indicated input variables is varied in turn with the other variables at their standard values (e.g., $\alpha$ varies from 0.2 to $10 \times$ its standard value). Note $x$-axis is logarithmic. The ranges in input values (standard values in parenthesis) are: $\theta$ (soil water content) $=0.1-0.8(0.53), f$ (diffusion impedance factor $)=0.5 \theta$ (Kirk 2004), $\mathrm{pH}_{\text {initial }}=4.5-8$ (6.1), $\left[\mathrm{Cl}^{-}\right]_{\text {initial }}=40-135$ (80) mM, $P_{\mathrm{CO}_{2}}=0.1-5$ (0.5) kPa (Kirk, 2004), $b_{\mathrm{HS}}{ }^{*}$ $(\mathrm{pH}$ buffer power $)=4-85(15) \mathrm{mmol} \mathrm{kg}^{-1} \mathrm{pH}^{-1}$ (Corstanje et al. 2008), $\alpha^{*}$ (precipitation rate constant) $=$ $0.1-5$ (0.5) $\mathrm{nmol} \mathrm{kg}^{-1} \mathrm{~s}^{-1}$ (Section 4.2.3). Time $=5 \mathrm{~d}$. ${ }^{*}$ Per unit soil mass basis 
Initial $\mathrm{pH}=5$

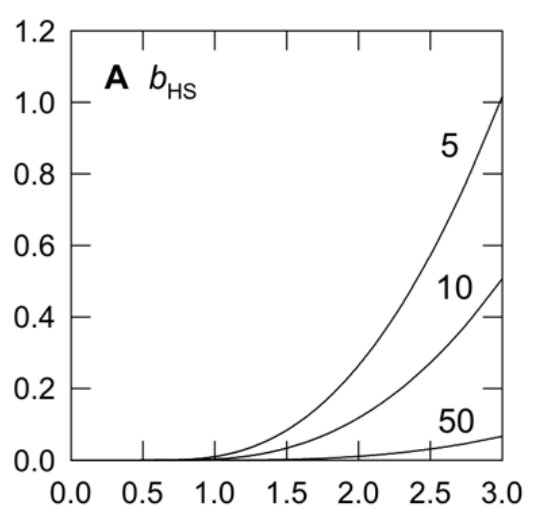

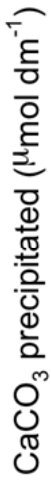
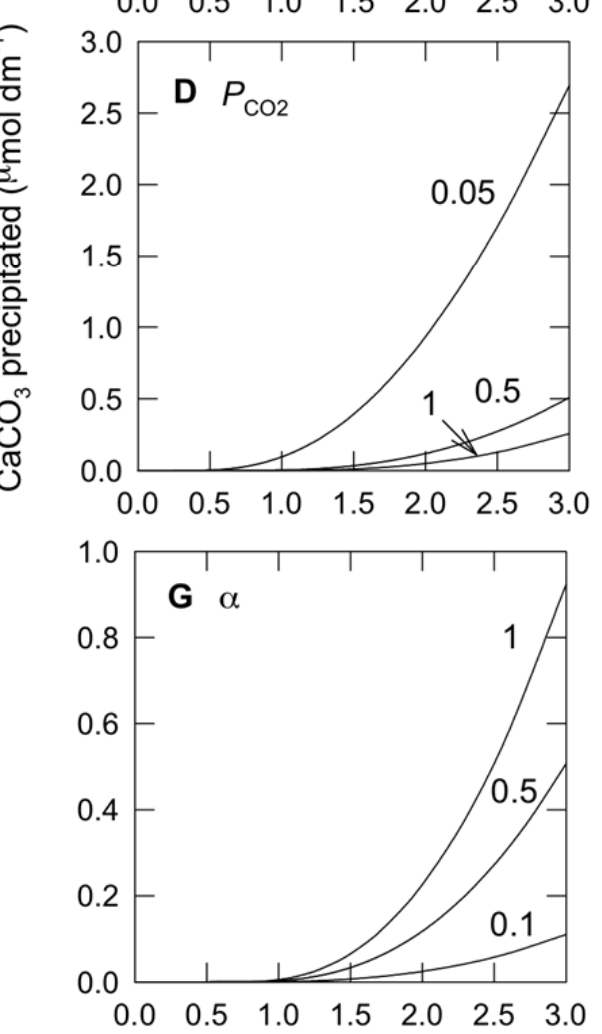

Initial $\mathrm{pH}=6$
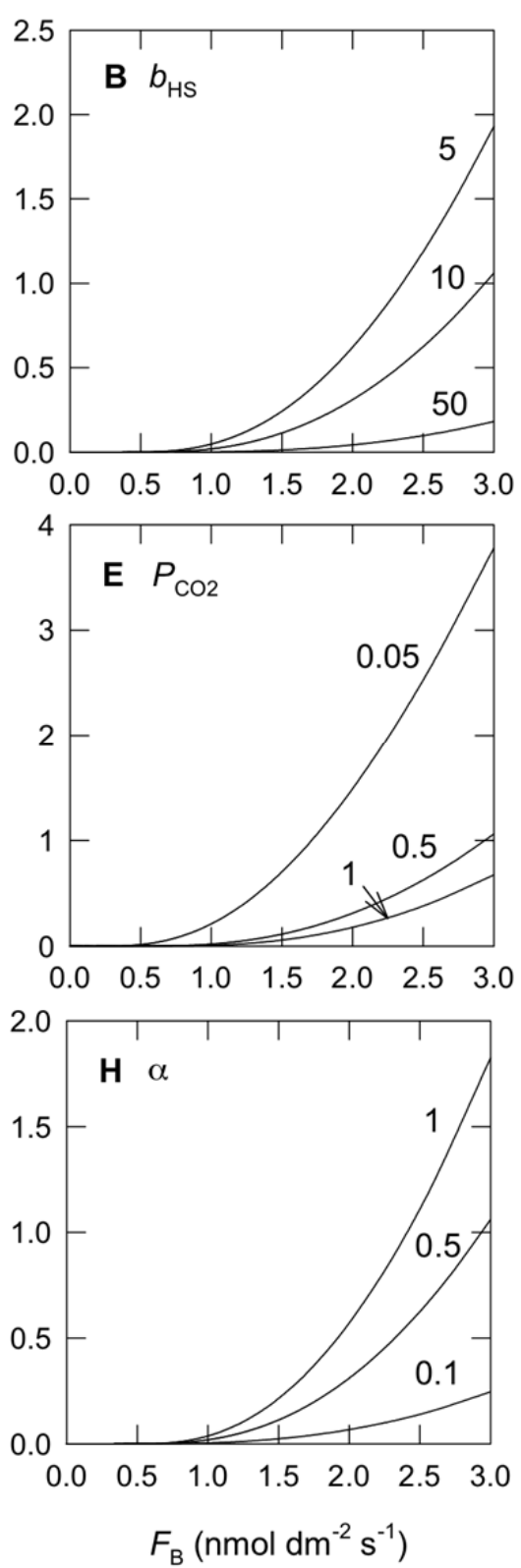

Initial $\mathrm{pH}=7$
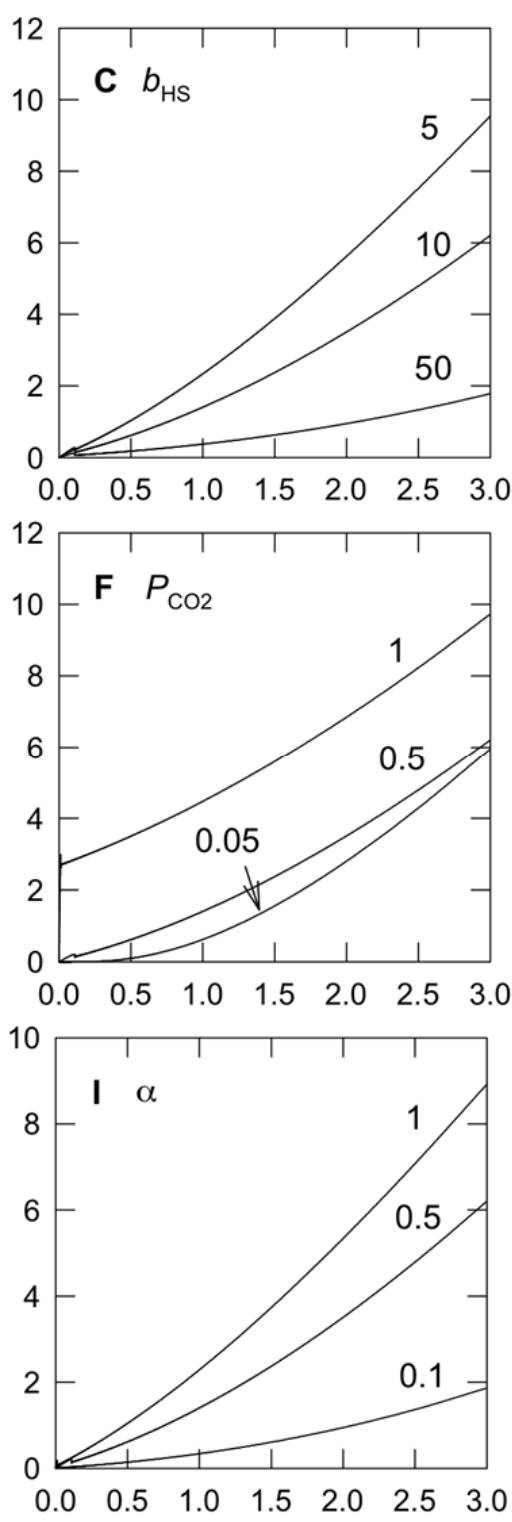

Fig. 4. Sensitivity analysis of the model in cylindrical geometry. The amount of $\mathrm{CaCO}_{3}$ precipitated per unit length of cylinder of internal radius $a$ is plotted against the flux of $\mathrm{HCO}_{3}{ }^{-}$ across $a\left(F_{\mathrm{B}}\right)$. The numbers on the curves are the values of the indicated variables. The effects of $(\mathrm{A}-\mathrm{C})$ soil $\mathrm{pH}$ buffer power $\left(b_{\mathrm{HS}}, \mathrm{mmol} \mathrm{dm}^{-3} \mathrm{pH}^{-1}\right)$, (D-F) $\mathrm{CO}_{2}$ pressure $\left(P_{\mathrm{CO} 2}, \mathrm{kPa}\right)$ and $(\mathrm{G}-\mathrm{I})$ precipitation rate constant $\left(\alpha, \mathrm{nmol} \mathrm{dm}^{-3} \mathrm{~s}^{-1}\right)$. Other parameter values are: initial $\mathrm{pH}=5,6$ and 7 (shown above panels); $\left[\mathrm{Ca}_{\text {total }}\right]$ set by Eq. (16); $\left[\mathrm{M}^{+}\right]=30 \mathrm{mM}$; $\left[\mathrm{Cl}^{-}\right]_{\text {initial }}=80 \mathrm{mM} ; a=0.002 \mathrm{dm}$; $R=0.052 \mathrm{dm} ; \rho=1 \mathrm{~kg} \mathrm{dm}^{-3} ; \theta f=0.02 ; t=10$ days. 
Initial $\mathrm{pH}=5$
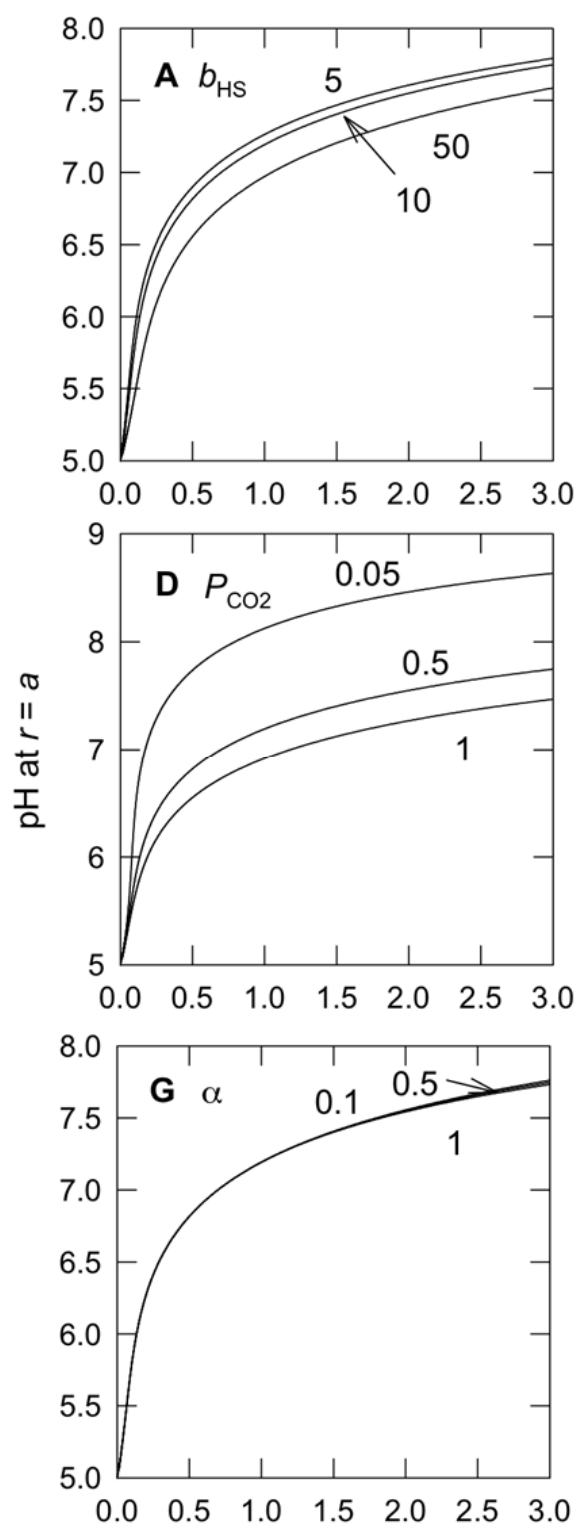

Initial $\mathrm{pH}=6$
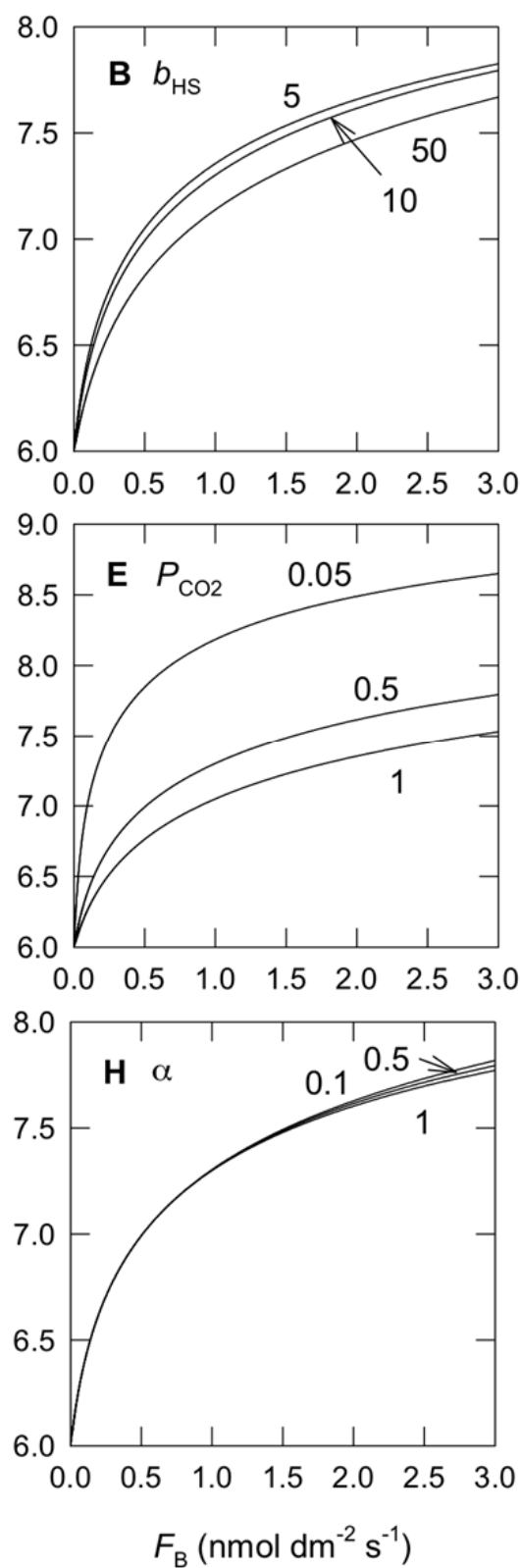

Initial $\mathrm{pH}=7$
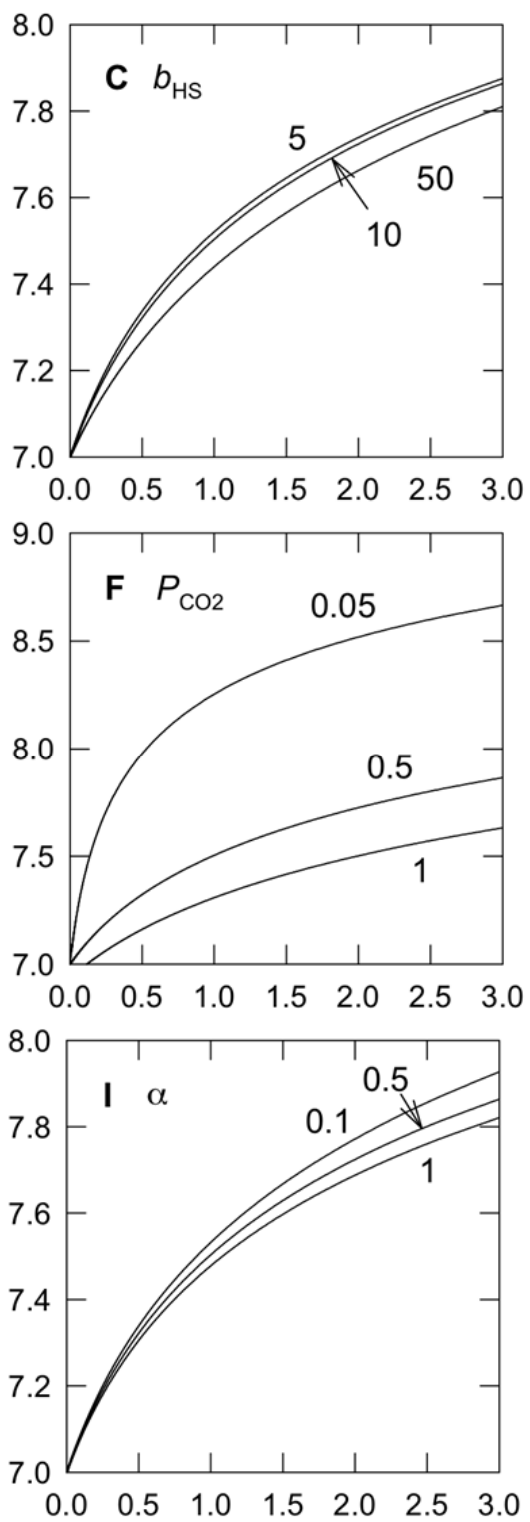

Fig. 5. Sensitivity analysis of the model in cylindrical geometry. The $\mathrm{pH}$ at the boundary $r=a$ is plotted against the flux of $\mathrm{HCO}_{3}{ }^{-}$across $a\left(F_{\mathrm{B}}\right)$. The numbers on the curves are the values of the indicated variables. Other parameter values as in Fig. 4. 


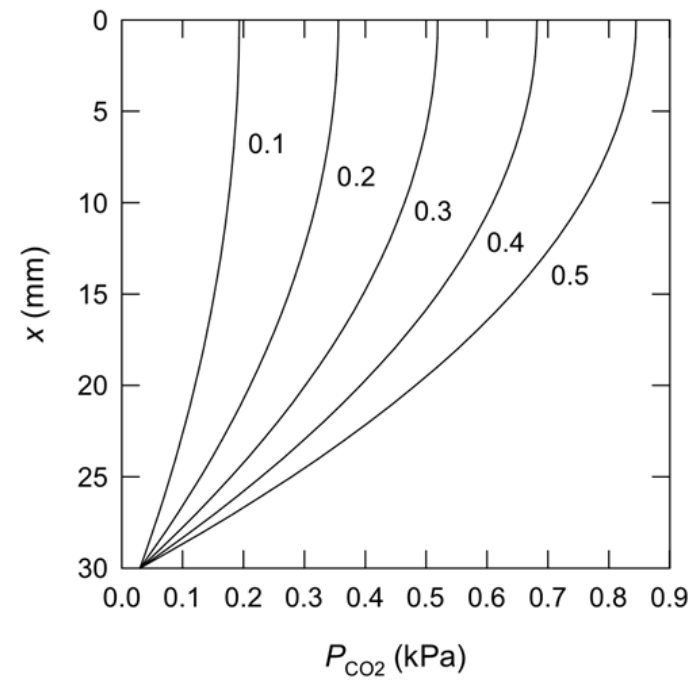

Fig. A1. Calculated $\mathrm{CO}_{2}$ gradients through the experimental soil columns for different rates of soil respiration (numbers on curves, units mmol $\mathrm{CO}_{2} \mathrm{dm}^{-3}$ soil h$^{-1}$ ). 